\title{
Mapping Sites: Lieux de Savoir in the Practice of Urban Cartography, 1340-1560
}

KEITH D. LILLEY (D)

बభН

Open Library of Humanities

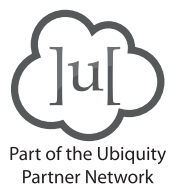

CORRESPONDING AUTHOR:

\section{Keith D. Lilley}

Queen's University Belfast, GB

k.lilley@qub.ac.uk

\section{KEYWORDS:}

maps; lieux de savoir; critical cartography; medieval; early-modern; city; historical geography; archaeology of cartography; surveying; landscapes; England

TO CITE THIS ARTICLE: Keith D. Lilley. "Mapping Sites: Lieux de Savoir in the Practice of Urban Cartography, 1340-1560." Le foucaldien 7, no. 1 (2021): 7, pp. 1-22. DOI: https://doi.org/10.16995/ lefou.96 


\section{INTRODUCTION: MAPPING THE FIELD}

As a "field of knowledge," the history of cartography has truly been shaped by the critical thinking of Michel Foucault. In a seminal and highly influential series of articles and papers in the late 1980s, J. Brian Harley drew attention to the importance of Foucauldian philosophies in what had been until then a largely a-theoretical and untheorized intellectual endeavour. ${ }^{1}$ The history of cartography it is fair to say was revolutionised by Harley, and reinvigorated interest in and critical engagement of maps and mappings across the social sciences and humanities. ${ }^{2}$ It has remained thus ever since, and Harley's work continues to inform critical debates in histories of cartography as well as historical geography. ${ }^{3}$ The basis of this "critical cartography" for Harley lay especially in Foucault's work on power, surveillance and technology, which Harley used to expose the "hidden" secrets of historic maps in particular. ${ }^{4}$ In so doing, Harley and others since seek to understand how a map's authority as a "truthful" representation of the material world derives from normative cartographic conventions, a language of maps which is now taken for granted, such as map-scale, orientation, and symbology. ${ }^{5}$ The finished map, Harley argued, concealed those subjectivities and decisions that went into a map's making, and it was this that gave maps (and map-makers) their power and esteem. ${ }^{6}$ This "power of maps" is manifest in all maps, not just particular genres of cartography.

While Harley's critical cartography has its detractors, there is no denying its continued dominance in Anglophone geographical circles when it comes to thinking through maps. ${ }^{8}$ Yet there is something of a paradox that remains to be resolved: cartographic practice-the making of maps-is rooted "in the field" yet histories of maps and mapping have neglected the significance of "the field" as a key site in map-making. Since maps are themselves "spatial representations," this a-spatiality in established histories of cartography is evidently contradictory. It is a criticism noted by others too, including Edney, who writes:

A key problem is that, despite the centrality of fieldwork to the modern cartographic ideal, map historians have been happy to leave fieldwork and surveying well enough alone, unexamined and untheorized. Even critical map scholars have avoided the issue of the relationship of fieldwork to graphic map. ${ }^{9}$

Not only is "the field" missing from current histories of cartography, its absence skews the subject as a result, for these "mapping sites" were locales of situated cartographic practice, of production, consumption and circulation, where maps and map-making took place. Part of the reason for this neglect of "the field" as a site of cartographic practice perhaps lies in a fixation and even fetishisation of the map image, and the power this holds over the map

1 J. Brian Harley, The New Nature of Maps: essays in the history of cartography, ed. Paul Laxton (Baltimore/ London: Johns Hopkins University Press, 2001).

2 Jeremy Crampton, "Maps as social constructions: power, communication and visualization," Progress in Human Geography 25 (2001): 235-52. Bernhard Klein, Maps and the Writing of Space in Early Modern England and Ireland (New York: Palgrave, 2001). Christian Jacob, The Sovereign Map. Theoretical Approaches in Cartography throughout History (Chicago: University of Chicago Press, 2006).

3 Denis Cosgrove, ed., Mappings (London: Reaktion, 1999). Keith D. Lilley, ed., Mapping Medieval Geographies. Geographical encounters in the Latin West and beyond, 300-1600 (Cambridge: Cambridge University Press, 2014).

4 Jeremy Crampton and John Krygier, "An introduction to critical cartography," ACME, an international e-journal for critical geographies 4, no. 1 (2006): 11-33. J. Brian Harley, "Maps, knowledge and power," in The Iconography of Landscape. Essays on the Symbolic Representation, Design and Use of Past Environments, ed. Denis Cosgrove and Stephen Daniels (Cambridge: Cambridge University Press, 1988), 277-312.

5 J. Brian Harley, "Deconstructing the map," Cartographica 26, no. 2 (1989): 1-20.

6 Harley, "Maps, knowledge and power," 299-300.

7 Denis Wood, The Power of Maps (London: Routledge, 1993). Chris Perkins, "Cartography: cultures of mapping, power in practice," Progress in Human Geography 28 (2004): 381-39.

8 John Andrews, "Meaning, knowledge and power in the map philosophy of J.B. Harley," in The New Nature of Maps: Essays in the History of Cartography, ed. Paul Laxton (Baltimore/London: Johns Hopkins University Press, 2001), 1-32. Martin Dodge, Rob Kitchin and Chris Perkins, eds., The Map Reader: Theories of Mapping Practice and Cartographic Representation (Chichester: Wiley-Blackwell, 2011), 4-5.

9 Matthew Edney, "Field/Map: An historiographic review and reconsideration," in Scientists and Scholars in the Field: Studies in the History of Fieldwork and Expeditions, eds. Kristian H. Nielsen, Michael Harbsmeier and Christopher J. Ries (Aarhus: Aarhus University Press, 2012), 431-56, at 432. 
viewer. Indeed, Harley's whole approach borrows much from art history, an "iconology" of cartographic representation. ${ }^{10}$

The map-image thus continues to hold power over those who seek to understand the "power of maps." ${ }^{11}$ On the other hand, the field, that place or site of cartographic creation and impulse which lies beneath or behind the map image, awaits excavation, disclosure. Hence the irony that exists in deploying a Foucauldian critique to expose maps as tools of surveillance but at the same time neglect a map's roots in survey. A case in point here is Pickles' History of Spaces, which does much to explore the role of cartography as an exercise in state surveillance, for example, yet "the field" as a mapping site-of sight through survey-is curiously silenced. ${ }^{12}$ Perhaps this is much to do with what Yann Calbérac observes, "the benefits that geographers have been able to derive from the tools and approaches provided by Foucault," which would include Harley and Pickles, yet it is fair to say too that geographers concerned with critical cartographies have equally sought to understand maps and mapping as "power relations at play in space." 13 Harley's approach to Foucault and to "maps, knowledge, power" is a skilful blend of both, though kept within the scopic and panoptic regime of the map, rather than "the field." ${ }^{14}$ What is still missing then is "the field," and those cartographic field-practices linking surveillance and survey.

This paper seeks to address this need to situate the map, to place it in the local landscape of its making. To do so, the focus here is the urban milieu of late medieval and early modern Europe. ${ }^{15}$ This period is typically seen by historians of cartography and geography as one characterised by a "revolution in the acceptance and use of maps" in Europe, indeed a shift that in itself is often mobilised to draw a distinct and firm line between "the medieval" and "the modern" worlds. ${ }^{16}$ So Miller observes, "As the relationship between the individual and the cosmos changes in the sixteenth century, so do the art and science of mapmaking. A different kind of map emerges, one that is often governed by more systematic and accurate measurements." 17 Thanks however to more nuanced analyses of specific maps and geographical works, this artificial divide between the fourteenth and sixteenth centuries has been questioned recently, for example, in reassessing the 1486 Ptolemy Edition by Johann Reger of Ulm, Hoogvliet notes, "Early Renaissance scholars were not seeking to declare inherited knowledge as useless but were trying to integrate the new with the old." ${ }^{18}$ This sense of continuity as much as change across this period is important, as it complicates orthodox histories of cartography, questioning those who separate medieval maps from modern, taking an alternative perspective to challenge orthodoxies just as Harley was seeking to do himself when he began questioning the "power of maps" by deploying the critical thinking of Michel Foucault. To explore further these shifting currents of cartographic praxis over the fourteenth and sixteenth centuries, there is a further

10 On "iconology" see Harley, "Maps, knowledge and power," 278-82. Harley's experimentation with an "iconography" of cartography is evident in J. Brian Harley, "Meaning and ambiguity in Tudor cartography," in English Map-Making 1500-1650, ed. Sarah Tyacke (London, The British Library, 1983), 22-45.

11 Wood, Power of Maps, 49.

12 John Pickles, A History of Spaces: Cartographic Reason, Mapping and the Geo-coded World (London: Routledge, 2004).

13 Yann Calbérac, "Close Reading Michel Foucault's and Yves Lacoste's Concepts of Space Through Spatial Metaphors," Le foucaldien 7, no. 1 (2021), DOI: https://doi.org/10.16995/lefou.90.

14 Keith D. Lilley, "Surveying empires: Archaeologies of colonial cartography and the Great Trigonometrical Survey of India," in Mapping Empires: Colonial Cartographies of Land and Sea, eds. Alexander Kent, Soetkin Vervust, Imre Demhardt and Nick Millea (Berlin/Heidelburg: Springer International Publishing, 2019), 101-20.

15 For a comprehensive assessment of European cartography of this period, see David Woodward, ed., The History of Cartography, Vol. 3. Cartography in the European Renaissance (Chicago: Chicago University Press, 2007). On English map-making in particular, Peter Barber, "Mapmaking in England, ca.1470-1650," in History of Cartography, Vol. 3, ed. Woodward, 1589-669. See also David Buisseret, ed., Monarchs, Ministers and Maps. The Emergence of Cartography as a Tool of Government in Early Modern Europe (Chicago: Chicago University Press, 1992).

16 Paul D. A. Harvey, Maps in Tudor England (Chicago: Chicago University Press, 1993), 7.

17 Naomi Miller, Mapping the City. The Language and Culture of Cartography in the Renaissance (New York: Continuum, 2003), xv.

18 Margriet Hoogvliet, "The medieval texts of the 1486 Ptolemy Edition by Johann Reger of Ulm," Imago Mund 54 (2002): 7-18, at 15 
Foucauldian dimension that may be brought into play through exploring 'mapping sites' in the practice of cartography. Jacob's lieux de savoir offers a new route. ${ }^{19}$

\section{LIEUX DE SAVOIR AND PLACING MAPS}

While lieu de savoir has gained currency and acceptance in European historiography on "spaces of knowledge," it has yet to make inroads into the Anglophone world. ${ }^{20}$ Here, drawing on lieux de savoir to situate cartographic practice is a step in this direction, for the idea of "sites of knowledge" speaks to the need to place maps, to locate them in and of "the field" and those landscapes from which they were literally drawn-out. Lieux de savoir provides a valuable conceptual point of connection too with contemporary engagements with Foucauldian thought and its critical application in current historical analyses of knowledge production and consumption in European cultures. ${ }^{21}$ It would seem then to be surely worthwhile to explore, as lieux de savoir, those sites within which and through which historic maps were made and used? To do so, here, the focus is on maps and cities of England of the fourteenth to sixteenth centuries, straddling deliberately therefore that contentious yet complicated "revolutionary" period of Western maps and map-making that still so dominates our thinking. ${ }^{22}$ What can we learn from placing maps and looking into "mapping sites"-the field—as locales of cartographic production?

In recent scholarship on the history of science a significant "spatial turn" has occurred..$^{23}$ The idea that geography matters in knowledge production has attracted greater attention across different arenas of past scientific endeavour, including especially spaces of exploration and discovery and their institutional settings of the Age of Enlightenment and Empire of the eighteenth and nineteenth centuries. ${ }^{24}$ Less focus has been given to earlier periods however, and where medieval and Renaissance "mapping places" have been examined-in Europe-the emphasis has been more on placing maps in their patronage settings and networks, or in terms of book- and atlas-making workshops, rather than sites of survey. ${ }^{25}$ Scope exists, therefore, in thinking through maps and their locales of production in and of "the field." Where the spatial turn has had more impact on histories of urban cartography is in the production of modern maps, such as those of the nineteenth century and their urban contexts, as in the case of Edinburgh and global cartographer John Bartholomew \& Co., based in the city. ${ }^{26}$ In "opening up

19 Christian Jacob, ed., Lieux de Savoir: Espaces et Communautés (Paris: Albin Michel, 2007). Christian Jacob, ed., Lieux de savoir. Vol 2, Les mains de l'intellect (Paris: Albin Michel, 2011). Christian Jacob, Qu'est-ce qu'un lieu de savoir? (Marseille, OpenEdition Press, 2014). Christian Jacob, "Lieux de savoir: Places and Spaces in the History of Knowledge," KNOW: A Journal on the Formation of Knowledge 1, no. 1, (2017): 85-102. Christian Jacob, Des Mondes Lettrés aux Lieux de Savoir (Paris: Les Belles lettres, 2018).

20 Stéphane Van Damme, "When practices, places and materiality matter: a French trajectory in the history of knowledge," Journal for the History of Knowledge 1, no. 1 (2020): 4; DOI: https://doi.org/10.5334/jhk.26.

21 Pieter Boonstra, "In Ecclesia Nostra: The Collatiehuis in Gouda and its Lieux de Savoir," Le foucaldien 7, no. 1 (2021), DOI: https://doi.org/10.16995/lefou.93; Margriet Hoogvliet and Sabrina Corbellini, "Writing as a religious Lieu de Savoir," Le foucaldien 7, no. 1 (2021), DOI: https://doi.org/10.16995/lefou.92. Luce Giard, Christian Jacob, Marc-Olivier Padis and Diane Sempere, "Les lieux de savoir: Pour une nouvelle cartographie des savoirs," Esprit 348, no. 10 (2008): 42-59.

22 Eg. "These maps reflect the transformation of spatial representation from the Middle Ages to the Renaissance and the shift from cartography based on historical events to one focused on topography: Miller, Mapping the City, xv. For an alternative overview, see Lilley, ed., Mapping Medieval Geographies. See also Anthony Gerbino, "Mastering the landscape: geometric survey in sixteenth-century France," The Art Bulletin 100, no. 4 (2018): 7-33.

23 David N. Livingstone, Putting Science in its Place (Chicago/London, Chicago University Press, 2003). Robert Mayhew and Charles W.J. Withers, eds., Geographies of Knowledge. Science, scale, and spatiality in the nineteenth century. (Baltimore/London: Johns Hopkins University Press, 2020).

24 David N. Livingstone and Charles W.J. Withers, eds., Geographies of Nineteenth-Century Science (Chicago: University of Chicago Press, 2011).

25 See Paul Fermon, Le Peintre et la Carte. Origines et essor de la vue figurée entre Rhône et Alpes (XIVe-XVe siècle) (Turnhout: Brepols, 2018), looks among other places at the papal court as a cartographic lieu de savoir; Katrin Kogman-Appel, Catalan Maps and Jewish Books. The Intellectual Profile of Elisha ben Abraham Cresques (1325-1387) (Turnhout: Brepols, 2020) emphasises the Jewish milieu of Mallorca in the fourteenth century; Jasper van Putten, Networked Nation. Mapping German Cities in Sebastian Münster's 'Cosmographia' (Leiden Boston: Brill, 2018) traces how, for his description of German towns, Sebastian Münster relied on experts in these town. See also John Andrews and Sarah Bendall, "Draft maps of Galway and Coventry for John Speed's Theatre of the Empire of Great Britaine," Imago Mundi 58, no. 1 (2006): 77-9.

26 Anna Feintuck, "Constructing cartographic authority: The conceptualization and mapping of urban spaces in Edinburgh, c.1880-c.1920," Urban History 46, no. 3 (2019): 464-92. 
the map," these spatially-situated studies of particular maps and map-makers have tended to examine more cartographic practice in the drawing office, those cartographers involved with drafting maps, working with geographical information gathered from the field, but looking at the production of the map-image again rather than the situated sites of survey that lie "behind the map." 27 So here is the challenge, to take these approaches, the spatial turn in the history of science broadly, and ideas on lieu de savoir, and "excavate" cartographic practices in and of "the field." These locales of cartographic production-mapping sites-mean reconnecting map and field, and in so doing seeing "the lieu de savoir as an activity [...] in which the spaces, the objects and the actors are studied in a continuous exchange and dynamic," 28 forged here through a dynamic relationship between urban map and urban landscape.

A starting point for unravelling this intersectional dynamic between "map" and "field" is a town-plan created in 1545 for the strategic naval English town of Portsmouth, on the south coast of England (Figure 1). ${ }^{29}$ The date of the making of this plan is significant not only in terms of its specific context, as part of the "defence of the realm" in the reign of Henry VIII which saw maps, perspectives and plans created as part of a reengineering and strengthening of coastal defences of England, ${ }^{30}$ but more broadly as a pivotal point in the trajectory of maps and mapmaking in England according to historians of English cartography.

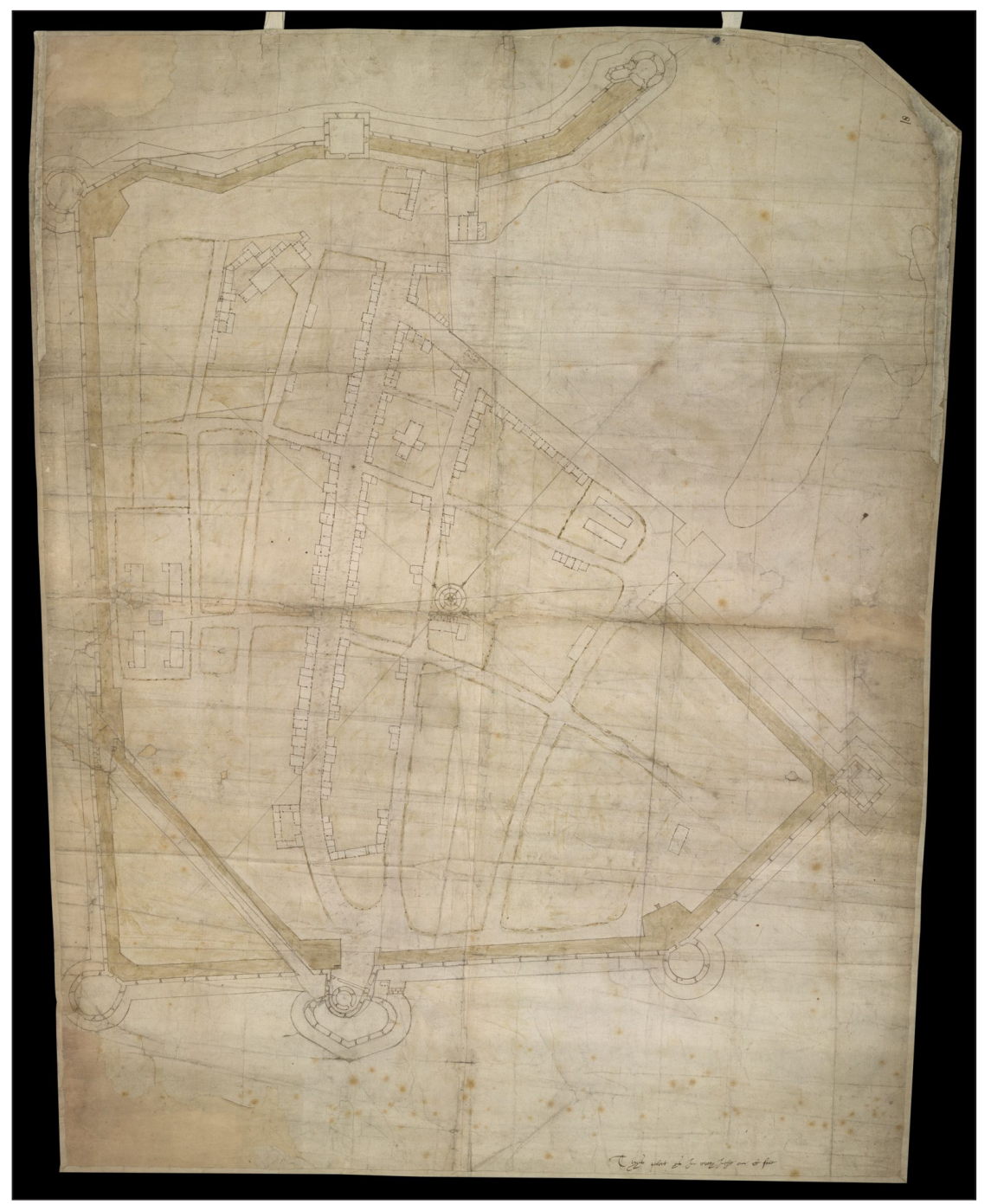

27 For more discussion, see Keith D. Lilley, "Mapping the nation: Landscapes of survey and the material cultures of the early Ordnance Survey in Britain and Ireland," Landscapes 18, no. 2 (2018): 178-99.

28 Hoogvliet and Corbellini, "Writing as a religious lieu de savoir."

29 "Plan of the fortifications of the town of Portsmouth" (1545), British Library, Cotton MS Augustus I i 81 . See Paul D. A. Harvey, "The Portsmouth Map of 1545 and the introduction of scale maps into England," in Hampshire Studies, ed. John Webb, Nigel Yates and Sarah E. Peacock (Portsmouth: Portsmouth City Records Office, 1981), $33-49$.

30 Howard M. Colvin, ed., The History of the King's Works, volume 4: 1485-1660 (Part 2) (London: Her Majesty's Stationery Office, 1982), 488-527, especially 504-8. John R. Hale, "The Defence of the Realm, 1485-1558," in History of the King's Works, volume 4, ed. Colvin, 367-401.
Figure 1 Plan of the fortifications of the town of Portsmouth (1545) (London, The British Library, Cotton MS Augustus I i 81), https://www. bl.uk/collection-items/surveyplan-of-portsmouth. 
By 1545 Portsmouth had already a long association with coastal defence, originating as a new town and port laid out at the end of the twelfth century when the town was then in the hands of Jean de Gisors. ${ }^{31}$ The layout of the town, with its curved grid of streets, was established in around 1180 at the time of its foundation and charter. ${ }^{32}$ By 1545. Portsmouth had not significantly changed in its layout, except for the creation of new fortifications, the raison d'être for the new plan. ${ }^{33}$ What is striking about this plan of Portsmouth is its use of planimetry, an ichnographic representation of the town's streets and defences drawn in plan-view, not perspective. Other contemporary urban maps in England at this time usually included took an oblique perspective view, usually of buildings, such as the map of Hull of 1539, another key English coastal post town. ${ }^{34} \mathrm{~A}$ further distinguishing feature noted by those who have remarked on the Portsmouth plan is its use of scale, as "the earliest map of any town in Britain to be drawn entirely as a scale ground-plan-no feature is shown pictorially," remarks Harvey. ${ }^{35}$ Indeed, the map's maker stated "Thys plat ys In every Inche on C fote." ${ }^{36}$ Historians of cartography commenting on this use of scale and planimetry have drawn attention to the role of Italian engineers in the refortification of coastal defences under Henry VIII in the 1530s-40s. ${ }^{37}$ Setting out new defences from plan, literally planning, through working from a scaled map, would clearly offer practical advantages for civil and military engineering, both in terms of the design for the defences, on where they should be sited, but also in terms of then positioning the defences on the ground, of laying them out. There is then a double meaning in the term "plat" used on the Portsmouth map, a "plat" as a drawn plan as well as a plan on the ground, the term being the same. $^{38}$

The idea that it is possible to work from plan had currency in England well before 1545 as is evident from an account in London, where, in 1415, the setting out of new gardens and "alleys being made therein lengthwise and across," just outside the city walls at Moorfields, were "plainly depicted and set forth on a certain sheet of parchment, made by way of pattern for the plans aforesaid," and moreover also "shown to the said Common Council, and exhibited." ${ }^{39}$ Such planning from plan might well be the purpose that lay behind the 1545 map in shaping the new defences of Portsmouth on the ground. This connection between map and field, between image and site, is therefore a dynamic one, written into the map as much as the landscape. There is more to this 1545 plan as a lieu de savoir however, and again the map-image hints at this. For on the drawn plan, at its centre, is a compass circle quartered by radiating lines extending outwards across the map sheet to intersect with the town's streets and defences. These lines on the map orientate the viewer therefore, the user of the plan, but also connect the map with "the field" as a site of knowledge. These radiating lines are not about delimiting the topography of the town but rather underpin the constructional geometry of the map.

There is more than a passing resemblance between the configuration of the Portsmouth plan and that of Imola of 1502 drawn by Leonardo da Vinci, with its similarly planimetric view of the urban landscape, drawn to scale, and central compass circle with radiating lines..$^{40}$ What is more, for Imola, as Pinto explains, "The unusual format of the Imola plan and its preparatory

31 Dominic Fontana, "Charting the development of Portsmouth harbour, dockyard and town in the Tudor Period," Journal of Maritime Archaeology 8 (2013): 263-82.

32 Keith D. Lilley, "Urban planning and the design of towns in the Middle Ages: The Earls of Devon and their 'new towns,'" Planning Perspectives 16 (2001): 1-24.

33 Harvey, "Portsmouth map of 1545."

34 British Library, Cotton MS. Augustus I.i.83, see Harvey, Maps in Tudor England, 40.

35 Harvey, Maps in Tudor England, 72, figure 49.

36 The 1545 map of Portsmouth is available free-to-view at: https://www.bl.uk/collection-items/surveyplan-of-portsmouth.

37 Marcus Merriman, "Italian military engineers in Britain in the 1540s," in English Map-Making 1500-1650, ed. Sarah Tyacke (London: British Library, 1983), 57-67.

38 Norman Thrower, ed., The Compleat Plattmaker. Essays on Chart, Map and Globe-making in England in the Seventeenth and Eighteenth Centuries (Los Angeles: UCLA Press, 1978).

39 Henry V. A.D. 1415. Letter-Book I, fol. clii (Latin), in Memorials of London and London Life: In the 13th, 14th and 15th Centuries, ed. Henry T. Riley (London: Longmans, Green \& Co., 1868), 614-15. The text in Riley is in translation. Keith D. Lilley, "Urban planning after the Black Death: Townscape transformations in later-medieval England (1350-1530)," Urban History 42, no. 1 (2015): 22-42.

40 Leonardo da Vinci, "A map of Imola" (1502), Royal Collection Trust: RCIN 912284. Available free-to-view online at: https://www.rct.uk/collection/912284/anbspmap-of-imola. 
drawings may thus be understood in terms of an important innovation in surveying, practiced by [...] Leonardo [...] in the opening years of the sixteenth century." ${ }^{141}$ Here, the trace of the map's own making through survey operations in the field, in the urban landscape, is embedded in the map-image of the city. The map is a record of its evolution therefore. As da Vinci made clear in the finished map, the practices that had shaped it, conventions, like the scale and compass, gave the map a visible manifestation of its scientific basis. Not only did these visible geometric lines instil a sense of trust in the map but so too in the map's maker, pointing to their skills and expertise in the field. So too in the case of Portsmouth, with those same radiating lines evident in da Vinci's plan for Imola making visible the field-practices of those who made it and surveyed the town. Whether this vivid cartographic similarity between the plans of Portsmouth and Imola reflects Italian connections between the two seems at least a possibility, not least since Henry VIII employed Italian architects and engineers in the planning of fortifications along south coast of England. ${ }^{42}$

Through reflecting the processes and practices of its making the 1545 plan of Portsmouth is thus itself a lieu de savoir, for the map-image is a physical and tangible "site of knowledge." Yet so too is Portsmouth of 1545 a lieu de savoir, in the sense of it too being complicit in the making of the map, a particular place in time and space that drew in those with the necessary skills and expertise to draw out from the field, from the landscape, an ichnographic plan of the town drawn to a consistent scale. The remainder of this paper explores further this "archaeology of cartography," an interplay between map and city as lieux de savoir, by focusing on English towns and cities between 1340 and 1560 as sites of cartographic production. It does so geographically, for like Foucault, "Geography must be at the heart of what I look into." ${ }^{43}$ Not so much through Geography as a discipline (though I am a Geographer) but through geography as a locale, as a spatial setting, a landscape, a mapping-site-"the field" through which a map is made. This is an area of developing concern within Geography, and especially among historians of the discipline whose spatial thinking on scientific practices and knowledge has sought to emphasise the importance of the geographical-in addressing the where, as much as the what, when, how and why. Thus there is a need to "attend more carefully to discrete local sites and the constraints they place on the language that is available to interlocutors," so Livingstone argues, for:

Those sites were not simply material spaces, grid-referenced locations in Euclidian space, mappable cartographic spots. They are about that, of course. But they are also to be thought of as social spaces, material venues whose identity is shaped in interaction with the human cultures that produce them. ${ }^{44}$

As lieux de savoir, these local sites-and sights - are as much about dynamics on the ground, then, as they are about the networks within which these sites are located in relation to each other. The two are not separable, and to this end the city as a cartographic lieu de savoir offers particular scope as cities are of course networked, spatially connected, as well as localised, spatially defined. Through focusing on mapping in the late medieval and early modern city, from the fourteenth through to the sixteenth centuries, the aim here is to take a "traverse" through time and space. ${ }^{45}$ Doing so reveals intersectional connections and continuities between urban worlds across the medieval-modern divide, and helps to question not only the trajectory of European maps and map-making over this period but also situate maps and map-making in their geographical locales, paying close attention to these lieux de savoir in the making of maps, their urban settings. Here, "urban cartography," then, is broader than about maps of towns and cities, it is as much to do with maps and map-making in towns and cities. To examine this, the

41 John A. Pinto, "Origins and development of the ichnographic city plan," Journal of the Society of Architectural Historians 35 (1976): 35-50, at 40.

42 Merriman, "Italian military engineers," 63-5. Barber, "Mapmaking in England," 1595-608.

43 Michel Foucault, "Questions à Michel Foucault sur la géographie," Hérodote: revue de géographie et de géopolitique 1 (1976): 71-85, at 85 .

44 David N. Livingstone, "Science, site and speech: scientific knowledge and the spaces of rhetoric," History of the Human Sciences 20 (2007): 71-98, at 73.

45 "Traverse", a field-survey technique involving "taking observations from successive instrument stations and [...] backsighting to the previous station:" Sarah Bendall, "Plane table," in History of Cartography, Volume 4 (Part

1). Cartography in the European Enlightenment, eds., Matthew Edney and Mary Sponberg Pedley (Chicago: Chicago University Press, 2020), 675-77, at 676. 
paper takes in three English provincial cities-Chester, Bristol and Norwich-each as a lieu de savoir shaped by cartographic practices at three particular points in time, the 1340s for Chester, 1480s for Bristol, and 1550s for Norwich, and three particular maps belonging to each. This traverse through time and space is at once a cartographic journey but also inherently an urban one.

\section{URBAN MAPPINGS-A TRAVERSE THROUGH CARTOGRAPHIC LIEUX DE SAVOIR}

Located in the north-west, south-west and east of England respectively, Chester, Bristol and Norwich each occupy distinct regional geographies, each functioning as provincial capitals with long-established urban roots and traditions by the fourteenth to sixteenth centuries. ${ }^{46}$ Yet they share certain characteristics economically, demographically and politically as cities distant from London, each outward facing, too, with strong overseas maritime links yet at the same time important in serving immediate hinterlands. By the time the "Gough Map" of Great Britain was compiled and drawn, perhaps in the late fourteenth century, perhaps in the fifteenth, these three cities each shared a similar standing in the urban hierarchy, as indicated by the map through having distinctive comparable "walled city" symbols marking their locations as well as their status..$^{47}$

The enduring influence of the anonymous Gough Map's geographical outlines of Britain, and the positioning of its towns and cities, is evident on those maps subsequently created, such as George Lily's map of 1546, Laurence Nowell's of c.1564 and Humphrey Llwyd's of 1568/73.48 Yet while these lasting cartographic resemblances between these different maps of Britain might point to certain continuations and perhaps even inertia in English map-making from the fourteenth to the sixteenth centuries, what is evident on the ground is anything but an apathy towards map-making, for within those locales represented on these "general" topographic maps, towns and cities across England were alive to practices of cartography, an "urban cartography." Here, then, these mapping-sites yield a more dynamic history of English mapconsciousness, a cartographic lieux de savoir rooted in 'the field.' The evidence for this localised and situated map-making is to be found in the activities of individuals in each of the three cities-Ranulf Higden (c.1280-1364) in Chester, Robert Ricart (fl. 1478) in Bristol, and William Cuningham (fl.1550s) in Norwich-each fusing their particular maps with their cities.

\section{URBAN MAPPING I: CHESTER, 1340—"THE WORLD IN THE CITY"}

The mappamundi, or "world map," of Ranulf Higden (Figure 2) has long attracted scholarly interest but more for its place within the Polychronicon in which is appears in a mid-fourteenth century manuscript than in relation to the city where Higden spent his life..$^{49}$ As an incumbent of St Werburgh's Abbey, located at the north-east corner of the walled city of Chester, Higden occupied a place at the very heart of city. Indeed, far from having a distant existence from the civic and commercial life of late-medieval Chester, the abbey had a close relationship with Cestrians. For instance, one of Higden's forebears, Lucian of Chester, in c.1200, wrote a panegyric for his home city, Le Laude Cestrie, celebrating the local landscape and drawing parallels between Chester's cross-shaped, fortified city-plan and that of the holy city, as if conjuring up for Chester a visual image of Jerusalem in textual form and then projecting this

46 For the three cities see: Jane Laughton, Life in a Late Medieval City: Chester, 1275-1520 (Oxford: Oxbow Books, 2008); Mary D. Lobel and Eleanor M. Carus-Wilson, "Bristol," in The Atlas of Historic Towns, Volume 2, ed. Mary D. Lobel (Oxford: The Scolar Press/Historic Towns Trust, 1975); James Campbell (1975), "Norwich," in The Atlas of Historic Towns, Volume 2, ed. Mary D. Lobel (Oxford: The Scolar Press/Historic Towns Trust, 1975).

47 Nick Millea, The Gough Map: The Earliest Road Map of Great Britain? (Oxford: Bodleian Library, 2007), 68-73; Keith D. Lilley and Christopher D. Lloyd C D, "Mapping the realm: a new look at the Gough Map of Britain (c.1360)," Imago Mundi 61, no. 1 (2009): 1-28. The Gough Map is accessible free-to-view online at goughmap.org/map/.

48 Cat Porter, Keith D. Lilley, Christopher D. Lloyd, Siobhán McDermott and Rebecca Milligan, "Cartographic connections - the digital analysis and curation of sixteenth-century maps of Great Britain and Ireland," e-Perimetron 14, no. 2) (2019): 97-109.

49 Raleigh A. Skelton, "Ranulf Higden," in Mappemondes A.D. 1200-1500, Monumenta cartographica vetustioris aevi 1, ed. Marcel Destombes (Amsterdam: N. Israel, 1964), 149-60; John Taylor, The Universal Chronicle of Ranulf Higden (Oxford: Clarendon Press, 1966); Evelyn Edson, The World Map, 1300-1492: The Persistence of Tradition and Transformation (Baltimore/London: Johns Hopkins University Press, 2007). 
onto the physical and material form of the city. ${ }^{50}$ In this sense then, Higden's Polychronicon, St Werburgh's and the mappamundi would together seem to hint at some heightened spatial sensibility and established geographical tradition within the abbey's precinct, the "field" through which this map of the world was drawn.

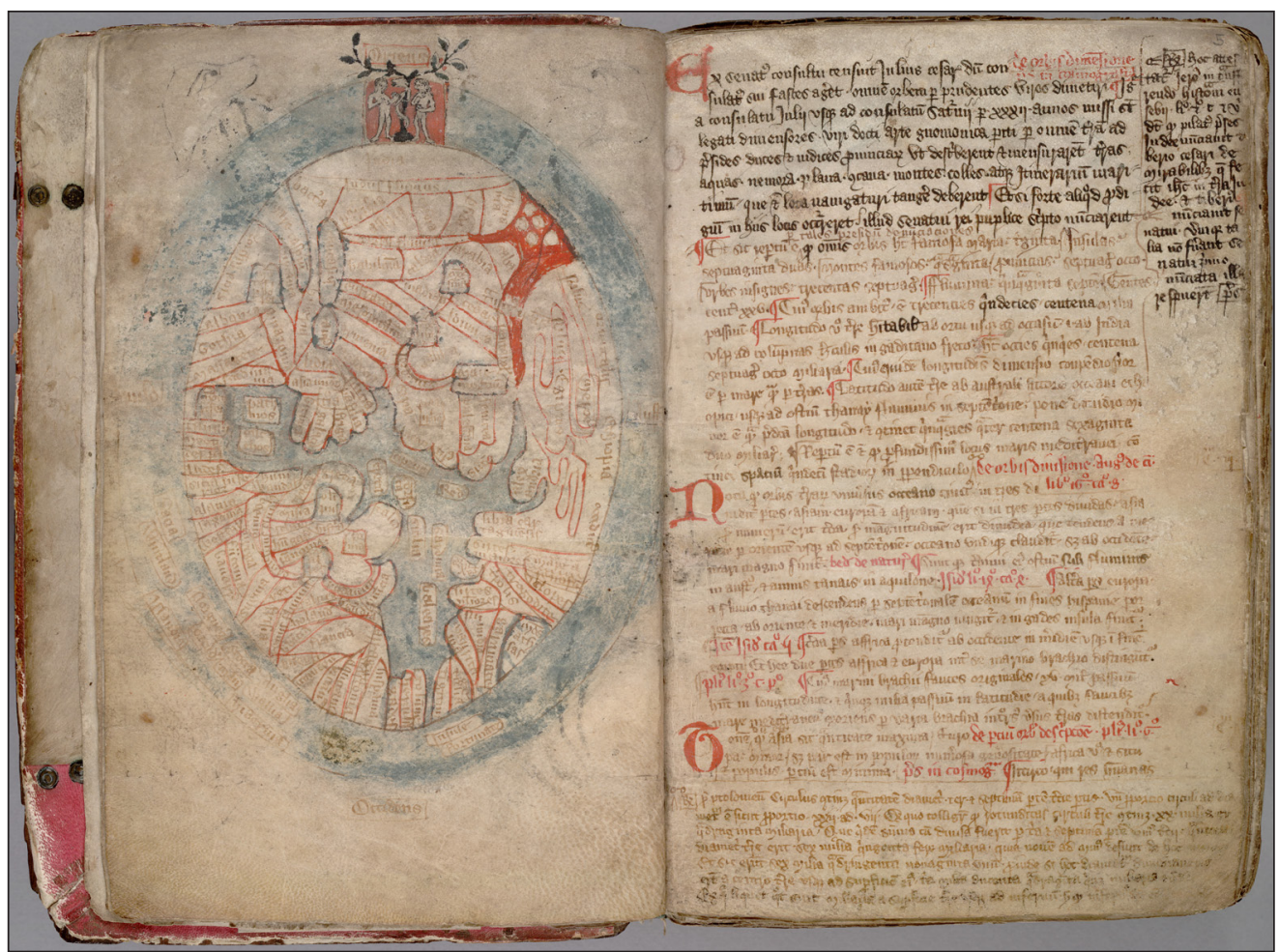

Chester's own geographical position at the north-west corner of England, itself at the northwest corner of the Latin Christendom, is something that Lavezzo draws attention to. ${ }^{51}$ Almost a paradox, she writes, that here at the very margins of the known late-medieval world, such concern for knowing the world-its history and its geography -is embodied by the Polychronicon, both in its text and its map, and rooted in the city by Higden and St Werburgh's. Yet, it would seem this spatial liminality of both England and Chester is precisely why there is such interest, locally, in the wider world that lay beyond the walls, bringing that world into the city, visually and textually. There is after all something special about Higden's Polychronicon, for not every such universal history of this period contained a visual geography even though the genre is characterised by textual geographies, a tradition tracing back to Classical precedents as well as medieval precursors. ${ }^{52}$

So Higden's mappa mundi points to something interesting and perhaps specific about the locale of its creation, Chester. It is not of course the visual geography of the map itself that places it in relation to Chester, Higden's map in fact does not show the city. The Polychronicon instead situates Chester textually in relation to other English cities of ancient origin such as London and York. Rather, it is the geographical situatedness of the map in the city that is significant. ${ }^{53}$ In this sense, the mappamundi is an instance of "urban cartography:" not a map of the city as such, but a map from the city as a lieux de savoir, as a mapping-site. As is so often the case for this

50 Keith D. Lilley, City and Cosmos. The Medieval World in Urban Form (London: Reaktion, 2009), 23-25. Mark Faulkner, "The spatial hermeneutics of Lucian's De Laude Cestrie," in Mapping the medieval City: space, place and identity in Chester c. 1200-1600, ed. Catherine Clarke (Cardiff: University of Wales Press, 2011), 78-98. For more on Lucian and a full transcription of the text, see http://www.medievalchester.ac.uk/texts/introlucian.html.

51 Kathy Lavezzo, Angels on the Edge of the World: Geography, Literature, and English Community, 1000-1534 (Ithaca/London: Cornell University Press, 2006), 71-92.

52 Cornelia Dreer and Keith D. Lilley, "Universal histories and their geographies: navigating the maps and texts of Higden's Polychronicon," in Finding your Place in History and Politics: the life of universal chronicles in the high Middle Ages, eds. Michele Campopiano and Henry Bainton (Woodbridge: Boydell and Brewer/York Medieval Press), 275-301.

53 Polychronicon Ranulphi Higden Monachi Cestrensis; together with the English Translation of John Trevisa and of an Unknown Writer of the fifteenth century, eds. Charles Babington and Joseph R. Lumby (London: Rolls Series, 1865-86). foucaldien

DOI: $10.16995 /$ lefou.96

Figure 2 Mappamundi, Ranulf Higden, Polychronicon (c. 1340) (San Marino, Huntington Library MS HM 132, folio 4v), https://digitalassets.lib. berkeley.edu/ds/huntington/ images//002198A.jpg. 
period in English cartography there are of course few indications of Higden's own cartographic practices, either in the Polychronicon itself or indeed from contemporary texts. What there is are hints at geographical sources for Higden's Polychronicon, and by implication too the accompanying map that appears in the only autograph copy of the text, now Huntington MS HM $132 . .^{54}$ The map in this version has been somewhat neglected compared to others to be found in fourteenth-century copies of the Polychronicon, partly probably due to some later versions, notably the British Library Royal MS 14 C IX, having more visually striking appearances, with its vivid colours and iconography. ${ }^{55}$ Yet it is Huntington MS HM 132 that takes us to Chester, to Higden, to St Werburgh's, to c.1340, the time of the map's compilation, and probably composition. ${ }^{56}$

Chester in 1340 was a thriving city, networked particularly into trading links with Ireland and Dublin. ${ }^{57}$ It was also a borderland city with a mix of Welsh and English influences. ${ }^{58}$ Even though Chester itself was firmly on the English side of the border with Wales here, the River Dee, on which the city lay, connected Chester to a rich and fertile agrarian hinterland of the Welsh Marches to the south and west. Higden himself noted too the city's long-standing strategic connections with north Wales and English struggles over Gwynedd and the string of the then relatively newly-founded castle towns of King Edward I (1272-1307) situated along the north coast between Chester and Anglesey/Ynys Môn..$^{59}$ This geographical positioning of Chester as a meeting point or crossing place between both near and distant cultures and regions perhaps begins to hint at a stimulus for this cartographic consciousness, or spatial awareness, of those who lived within its walls, despite the city's apparent liminality. Indeed, borderlands as hybrid spaces are often characterised by innovation and openness, the urban milieu in such locations propagating a sense of greater need and desirability because of the tyranny of distance created by their liminality and marginal geographies? It is a case here, then, of bringing the world to the city rather than the city to the world. As an exercise in geographical appropriation, Higden's mappamundi in Chester does just that, it orientates the city and its community to the wider world beyond their immediate horizons, drawing into the walled city those lands that lay distant. This is not simply an imagined geography, or a geography of the imagination, for the mappamundi that Higden created borrows certain tropes and characteristics of other contemporary world maps, not least, further south along the Welsh border, the now celebrated Hereford mappamundi created c. $1300 .{ }^{60}$ Just a few decades later, Higden compiled his Polychronicon and felt the need and desire in it to include a similar "visual geography" of this wider world, mapping beyond his own spatial horizons.

Something of these connections that existed between world-maps in fourteenth-century England, and the urban networks involved in their mobility, is revealed by comparing the mappamundi that appeared in contemporary copies of Higden's Polychronicon. In particular, the representation of Britain and Ireland on these mappaemundi yields something of the likely influences of the locales of their production, highlighting further the dynamic nature of urban lieux de savoir in acts of map-making in English cities at this time. Such a comparison is made possible because Higden's Polychronicon was swiftly, widely copied so present in other monastic houses across the land, some physically distant from Chester itself but each likewise rooted in particular urban locales and their communities. ${ }^{61}$ Five such examples are oval-shaped maps

54 Vivian H. Galbraith, "An Autograph MS of Ranulph Higden's Polychronicon," The Huntington Library Quarterly 23 (1959): 1-18. The Huntington Higden map is accessible online free-to-view at: https://dpg.lib.berkeley.edu/ webdb/dsheh/heh_brf?Description=\&CallNumber $=H M+132$

55 British Library, Royal MS 14 C IX, fols. 1v-2r and fol. 2v. See Evelyn Edson, Mapping Time and Space. How Medieval Map Makers Viewed their World (London, British Library: 1997), 126-31. The "Royal MS" Higden map is accessible online free-to-view at: http://www.bl.uk/manuscripts/FullDisplay.aspx?ref=Royal_MS_14_C_IX.

56 Galbraith, "An Autograph MS." Dreer and Lilley, "Universal histories and their geographies."

57 Laughton, Life in a Late Medieval City: 173-6.

58 Catherine Clarke, ed., Mapping the Medieval City: Space, Place and Identity in Chester c. 1200-1600 (Cardiff: University of Wales Press, 2011).

59 Eg. "Idcirco rex Edwardus adveniens Cestriam circa festum sancti Nicholai [1296] cepit insulam Angleseyam, ædificavitque de novo urbem et castrum de bello Marisco:" Ranulph Higden, Polychronicon, ed. Lumby, vol. VIII, 282.

60 Paul D. A. Harvey, ed., The Hereford World Map: Medieval World Maps and their Context (London: The British Library, 2006).

61 Dreer and Lilley, "Universal histories and their geographies," 286-300. 
that collectively show, at the "corner" of the terrestrial world, England, Scotland, Wales and the Isle of Man as an assembled group of schematic shapes all of approximately equal size. ${ }^{62}$ Moreover, the origins of these particular manuscripts can be traced and placed geographically in particular urban/monastic locales, namely St Werburgh's Abbey at Chester, Ramsey Abbey (Huntingdonshire), Norwich Cathedral Priory, and one each at St Oswald's Priory and St Peter's Abbey at Gloucester, and placed chronologically in sequence from the 1330 s to c. 1400.63

The result of this mapping out of the geographies of Polychronicon mappaemundi is revealing when the maps and their locales are considered together. There is little overall cartographic convergence, each having particular nuance, such as the two Gloucester examples, from two adjoining yet distinct monastic houses in the centre of the city. ${ }^{64}$ St Oswald's mappamundi differs from its neighbour's at St Peter's, despite both manuscripts being broadly similar in date. While St Peter's version chose the ovoid scheme for depicting Anglia on the map in their manuscript (Corpus Christi College MS 89, fol. 13v), the adjacent Augustinian Priory of St Oswald employed four detached rectangles to depict England, Wales, Scotland and the Isle of Man, akin to Higden's autograph version. ${ }^{65}$ So as far as the two Gloucester examples are concerned was spatial proximity between monastic houses a factor behind subtly dissimilarlooking maps? It seems their particular mapping-sites mattered, with each locale-lieux de savoir-having a bearing on the individual mappamundi produced, which points rather more to an influence of geographical specificity in how Higden's Polychronicon was being read and copied in later-medieval England.

\section{URBAN MAPPING II: BRISTOL, 1480-"THE CITY IN THE WORLD"}

While Higden's Polychronicon and its mappamundi evidently circulated widely across English urban networks through the mid- to late-fourteenth century, its roots, its origins, lay in one particular city. This rootedness and specificity in urban mappings of the later Middle Ages can be explored further by turning to Bristol, which like Chester occupied a key geographical position facing out towards the Atlantic. ${ }^{66}$ Indeed, both Chester and Bristol shared in their maritime connections with Ireland especially, and by the end of fifteenth century increasingly linked to expanding European horizons and interest westwards. One of the city's particular geographically-minded inhabitants at this time, new to Bristol in the 1490s, was the Venetian John Cabot, who arrived via London having there visited the king, and made "hym sylf verray expert \& kunnyng In knowlage of the cyrcuyte of the world and Ile landis of the same, as by a caart \& othir demonstracions Reasonable." ${ }^{17}$ Cabot's cartographic consciousness in latefifteenth century Bristol would have slotted effortlessly into what was then very much a mapminded city, for its Town Clerk, Robert Ricart, had in 1479-80 begun to compile a civic record, The Maire of Bristowe is Kalendar, complete with map. ${ }^{68}$

Ricart's Kalendar as a register for the city of Bristol is by no means unusual for later medieval England, but it is rather exceptional in having in it an image of the city. There would appear to be something unusual, therefore, about how those within Bristol at this time perceived the need for a visual geography of the city in a book about the city created for the city, and also the function this image served for the urban community in the 1490s. This Kalendar had been commissioned in 1479 by William Spencer, the then mayor of the city of Bristol, who tasked

62 These five manuscripts being: Huntington Library SM MS 132 (c.1330), British Library Royal MS 14 C IX, f. 2v (1340s), BNF MS lat. 4922 (c.1390), Bodleian Library Tanner 170 (late-14 ${ }^{\text {th }}$ cent.) and Oxford Corpus Christi College MS 89 (c.1400).

63 Dreer and Lilley, "Universal histories and their geographies," 291-5.

64 For the medieval urban topography of Gloucester see Nigel Baker and Richard Holt, Urban Growth and the Medieval Church. Gloucester and Worcester (London: Routledge, 2004), 35.

65 Dreer and Lilley, "Universal histories and their geographies," 291-3.

66 Eleanor M. Carus Wilson, The Overseas Trade of Bristol in the later Middle Ages. Bristol Record Society, Vol. 7 (1937).

67 The Great Chronicle of London, eds., A. H. Thomas and Isobel D. Thornley (London: Corporation of the City of London, 1939), 287-8.

68 Bristol Record Office (BRO) 04720. The Maire of Bristowe is Kalendar, c.1480, ed. Lucy Toulmin Smith (Camden Society, New Series 5, 1872). The map is reproduced in colour in Peter Fleming, ed., The Maire of Bristowe is Kalendar (Bristol Record Society, Vol. 67, 2015): 32. Accessible free-to-view online at https://www.bristol.ac.uk/ Depts/History/bristolrecordsociety/publications/brs67.pdf. 
Robert Ricart to compile the work. ${ }^{69}$ The book ostensibly provided a record and account of the city's civic statutes with lists of mayors interspersed with descriptions of significant events. ${ }^{70}$ The opening pages of the Kalendar are devoted to the origins of Bristol, as Ricart himself observes,

For asmoche as it is righte conveniente and accordinge to euery Bourgeis of the Towne of Bristowe, in especiall thoo that been men of worship, for to know and vnderstande the begynnyng and first foundacion of the saide worshipfull Toune. ${ }^{71}$

It is as part of this historical framing for the city, right at the start of the volume, that the image of Bristol is inserted, taking up nearly a full page, and representing the inner, walled city (Figure 3). With its circle of walls, cross of streets pierced by four gates the styling of Bristol here visually compares with visualisations of the Heavenly and Earthly Jerusalem. ${ }^{72}$ There is however a more spatially localised field for the map-image, for it effectively focuses on the part of the city that was of earliest in origin, dating back perhaps to the ninth century. ${ }^{73}$ The image Ricart included - and the likelihood is the image and text were both a product of his own hand-took the viewer back in time, to the very foundations of Bristol, and present a stylised image of the city's initial layout.

While historians of cartography have tended to refer to the image of Bristol as a "map," "bird's eye" or a "plan," these are modern-day descriptions. ${ }^{74}$ The oblique perspective image of the city follows immediately on from a passage in the Kalendar relating to an account of its founding, which fits within a historiography of British urban foundations popularised by Geoffrey of Monmouth's mid-twelfth century Historia regum Britanniae (History of the Kings of Britain). ${ }^{75}$ Although the Historia does not explicitly mention Bristol, its genealogy is used by Ricart however to situate the city within a legendary history and geography of Britain and the cities founded by its ancient rulers, thus on folio $5 v$ Ricart states:

And then Brynne first founded and billed this worshipfull Toune off Bristutt that nowe is Bristowe and set it upon a litell hill. That is to say, bitwene Seint Nicholas yate, Seinte Johnes yate, Seinte Leonardes yate, and the Newe yate. And nomore was bilde not many yeres after. And thenne Brynne repaired home ovir see in his oune Lordeshippes of Burgoyne and there abode al his lyf. And King Bellyne abode at Newe Troy, and bilde there a noble yate fast by the watir of the Tamys, and called it Bellyngesgate aftir his oune name; and reignid nobly all his lyf, and lieth at Newe Troye. $^{76}$

This topographical account roots the city's late-fifteenth century landscape in Bristol's distant past. Here Ricart thus connects Bristol's visible urban features to their mythical founder "Brynne," drawing a parallel with London's associations with Belinus (Brynne's brother), and similarly orientating Bristol spatially and temporally to the past through its manifest material and physical form. ${ }^{77}$ The image of the city in the Kalendar immediately follows this topographical account, filling the rest of the page, as if words alone were not enough. Through materialising the form of the city visually, through an image, Ricart shows a cartographic sensibility, a map as much as a text was intelligible to the Kalendar's audience.

69 Peter Fleming, "Making history: culture, politics and The Maire of Bristowe Is Kalendar," in Reputation and Representation in Fifteenth-Century Europe, eds., Douglas L. Biggs, Sharon D. Michalove and A. Compton Reeves (Leiden/Boston: Brill, 2004), 289-316.

70 Fleming, ed., Maire of Bristowe is Kalendar: 3-7.

71 The Maire of Bristowe is Kalendar, Fol. 3b. Toulmin Smith, ed., Maire of Bristowe is Kalendar: 8.

72 Lilley, City and Cosmos, 20-1.

73 Keith D. Lilley, "Materialising the city: mapping in the imaging and imagining of medieval urban spaces," in Kommunale Selbstinszenierung. Städtische Konstellationen zwischen Mittelalter und Neuzeit, eds., Martina Stercken and Christian Hesse (Chronos Verlag: Zürich, 2018), 241-52.

74 Elizabeth Relph, "Bristol, circa 1480," in Local Maps and Plans from Medieval England, eds., Raleigh A. Skelton and Paul D. A. Harvey (Oxford: Clarendon Press, 1986), 309-16.

75 Lilley, "Materialising the city," 244-8. On the Historia see The Historia regum Britanniae of Geoffrey of Monmouth, ed., Julia C. Crick (Woodbridge: Boydell \& Brewer, 1991). Francis Ingeldew, "The Book of Troy and the genealogical construction of history: the case of Geoffrey of Monmouth's Historia regum Britanniae," Speculum 69 (1994): 665-704

76 The Maire of Bristowe is Kalendar, Fol. 5v. Toulmin Smith, ed., Maire of Bristowe is Kalendar: 10.

77 Lilley, "Materialising the City," 246. 


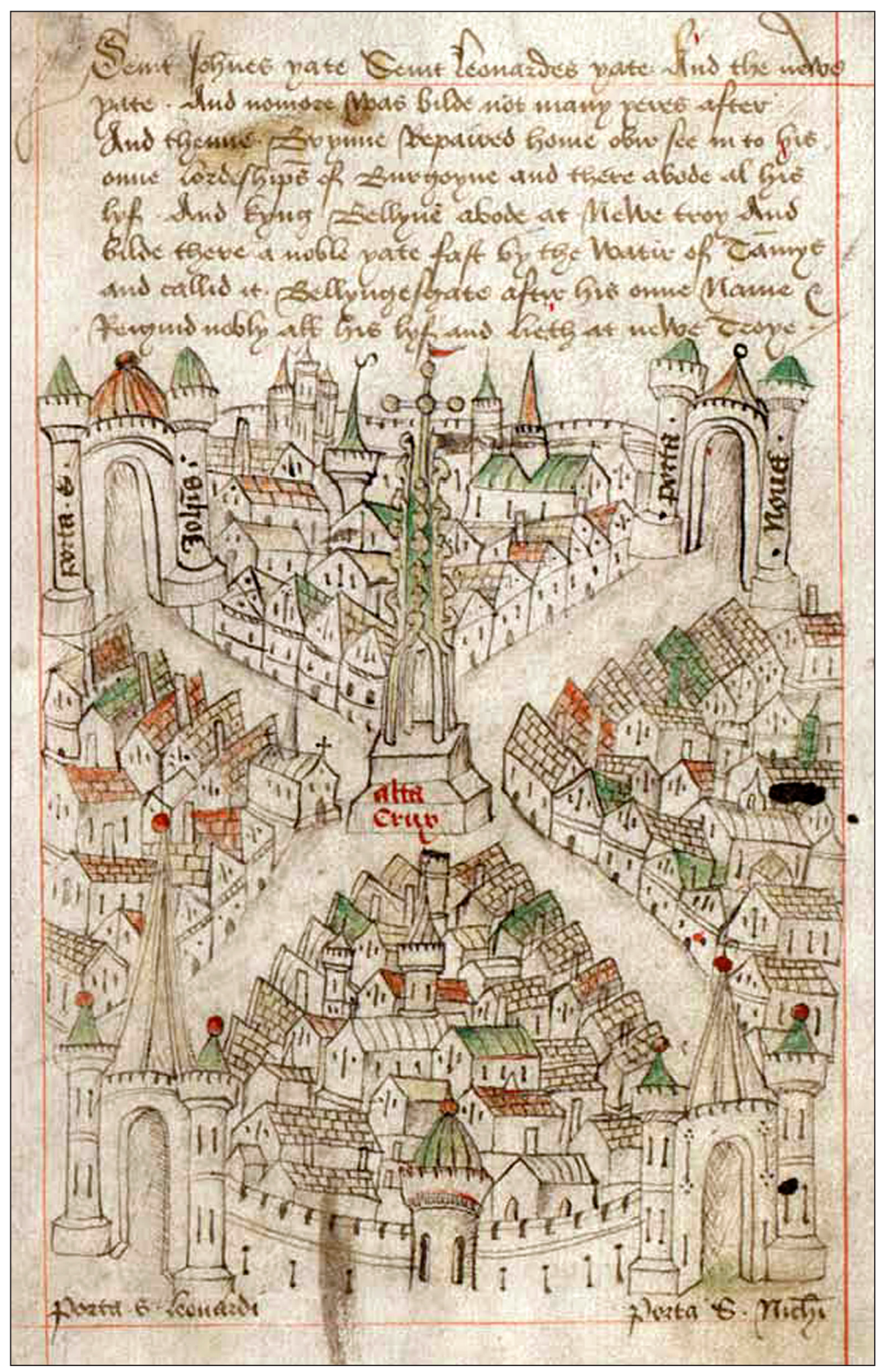

By the 1470 s and 1480 s, as Ricart was compiling the Kalendar, Bristol's merchants had wide maritime networks along the eastern Atlantic littoral, from Iberia to Iceland. ${ }^{78}$ This broad geographical compass of Bristolians at this time is indicated, for example, by William Worcestre, a contemporary of Ricart's and also writing in Bristol in c. $1480 .{ }^{79}$ In his Itineraries Worcestre thus observed,

In 1480 , on July 15 , the ship of John Jay the younger began a voyage from the Kingrode of Bristol to the island of Brasylle beyond the western part of Ireland, to traverse the seas [...] And Thyld [John Lloyd] is most expert shipmaster in all England, and news came to Bristol on Monday the 18th of September that in the said ship they sailed the seas for about nine months [sic, weeks] and did not find the island,
Le foucaldien

DOI: $10.16995 /$ lefou.96

Figure 3 View of Bristol, Robert Ricart, The Maire of Bristowe is Kalendar (c. 1479-80) (Bristol, Bristol Record Office (BRO) 04720, fol. 3b), https://upload. wikimedia.org/wikipedia/ commons/a/ad/1478_Robert Ricart map of Bristol\%2C England.png.

78 Carus Wilson, Overseas Trade of Bristol, see also David B. Quinn, England and the discovery of America, 14811620: from the Bristol voyages of the fifteenth century to the Pilgrim settlement at Plymouth: the exploration, exploitation, and trial-and-error colonization of North America by the English (New York: Alfred A. Knopf, 1974). 
but were driven back by storms to a port [...] in Ireland for the refreshment of the ship and the men. ${ }^{80}$

The "island of Brasylle" had long attracted the interests of mariners, ${ }^{81}$ and for Bristol this had two important implications, for such ventures brought geographical knowledge and navigational experience to the city, and this itself increased the city's cartographic consciousness. Bristol's "map-mindedness" of the 1480s and 1490s, is expressed though Ricart's Kalendar and his use of a visual image of the city, as well as by those like him inhabiting the city at this time, including John Cabot and William Worcestre. Worcestre's Itineraries reveal this growing geographical impetus in late-fifteenth century Bristol, for example. In an entry on Ireland, he lists "The ports and havens in their right order," by which he meant their right geographical order, as if reading from a map, or onto a map, the locations of the ports he lists: "Waterford, Wexford, Arklow, Wicklow, Dublin, Howth, Malahide, Rogers Town, Boyne, Dundalk, Carlingford, Strangford, Carrickfergus." 82 Such accounts hint at an inherent geographical awareness among those Bristolians at this time, not just an interest in the wider world but a means for organising it and recording it, thus linking the city to the world.

Amongst this mapping milieu of Bristol in the 1480s and 1490s, John Cabot arrived from London.83 It was surely not just Bristol's geographic maritime Atlantic seaboard location that attracted him there, but the reputation of the city's geographical-and cartographicknowledge and expertise, a "mapping-site"? Cabot took up residence in the walled core of the city, the very area "mapped" by Ricart in the Kalendar, just a few streets distant from John Jay's house. ${ }^{84}$ Situated between them both at this time lay the residence of Nicholas Thorne, another Bristol merchant with geographic and cartographic interests. Thorne had endowed the then newly-founded Bristol Grammar School and at his death, in 1546, bequeathed, "all such books as I have meat for the said library, more my astrolabia, which is the keeping of John Sprynt, [a]poticary, numbers of cardes etc., maps and all such instruments belonging to the science of astronomye or cosmography." 85 These maps and instruments of Thorne's are not precisely known from his will, but point to an expertise in their use among Bristol's merchants at this time, ${ }^{86}$ those men seeking distant lands across the sea, and those who saw the need to illustrate their civic register with a map. Here, then, Bristol is functioning as a cartographic lieu de savoir in the later decades of the fifteenth century. The city's geographical position, as well as its geographical reputation, mutually reinforcing one another, such that in his search for new worlds, across the Atlantic, Cabot set sail for the Americas in 1497.87

\section{URBAN MAPPING III: NORWICH, 1559-"THE CITY AS A WORLD"}

"In the England of 1500 maps were little understood or used," observed Paul Harvey in his book, Maps in Tudor England. ${ }^{88}$ Bristol and its mapping sites in around 1500 might stand as an exception, a curious and productive combination of both "geography" as setting and "Geography" as discourse. Or perhaps instead there were others, elsewhere, for Bristol did not stand alone, isolated, but was instead thoroughly networked in an urban hierarchy connecting towns and cities across the land. This "geography of geography" in an English provincial city is glimpsed through the example of Bristol therefore. So rather than seeing 1500 as a magical

80 Worcestre, Itineraries, ed., Harvey, 195 (1480).

81 Quinn, England and the Discovery of America, 59-60; Thomas J. Westropp, "Brasil and the legendary islands of the North Atlantic: their history and fable. A contribution to the 'Atlantis' problem," Proceedings of the Royal Irish Academy 30 (1912-13): 223-60.

82 Worcestre, Itineraries, ed., Harvey, 245 (1479).

83 The Cabot Voyages and Bristol Discovery under Henry VII, ed., James A. Williamson, Hakluyt Society, 2nd series, 120 (1962).

84 Lilley, "Materialising the medieval city," 249-50.

85 Bristol Record Office, 04421, fol.276.

86 The kind of maps, "cardes etc" that merchants in Bristol might have had access to at this time is indicated by the contemporary "Paris Map," of c.1490 (Bibliothèque Nationale de France, AA 562) and probably composed in Portugal, for Quinn suggests, "we may use the Paris map... as [a] cartographical indication of the Atlantic as John Jay, Thomas Croft and their successors of the early 1490s saw it: " Quinn, England and the Discovery of America, 62. The "Paris map" is accessible free-to-view at http://expositions.bnf.fr/marine/grand/por_013.htm. 
turning point in the history of English cartography perhaps it is more a staging point on a journey, in as much as Ricart's drawing upon Geoffrey of Monmouth for Bristol in the Kalendar reflects continuity in geographical and historical knowledge? This all points to the important role cities play as lieux de savoir in intersecting geographies past, present and future. While the sixteenth century might now, in Harvey's words, be seen as a time of "cartographic revolution in England," there are grounds to at least think again.

Second only to London in the 1520s, Norwich, like Bristol, occupied a significant place high in England's urban hierarchy, both cities by then extending in size well beyond their original cores. ${ }^{89}$ Rather than looking west, to the Atlantic, Norwich looked east, across the "German Sea" to the Low Countries, and had long done so. In 1401-02, as part of the improvements of the River Wensum in the city, a certain William Fulkes was sent from Norwich to Colchester, in order "to consult there with a man called Blaumester." ${ }^{190}$ A year later Blaumester was then brought across to Norwich and paid twenty shillings by the city "for examining the place for the water mills to be newly built," the man's surname pointing to Flemish family origins (ie. Bouwmeester), an architect or master mason, and thus someone competent in matters of planning and design. ${ }^{91}$ These connections between eastern England and the Low Countries by the sixteenth century were further cemented through a shared and long-standing need for civil engineering required for draining lower-lying land, a task involving expertise in surveying, not just for levelling for water-management of dykes and canals but for measuring, for creating new land parcels, for dividing these up and allocating them, for which maps were often drawn. ${ }^{92}$ It is perhaps not surprising, then, that in Skelton and Harvey's "map of maps" of late medieval England there is a marked geographical bias towards the eastern counties of England in the spatial distribution of "local maps." 93

As with Bristol, for Norwich the earliest extant map of the city (Figure 4) forms part of a text itself the work of a local man, William Cuningham. ${ }^{94}$ Written in Norwich and published in 1559 in London, The Cosmographical Glasse is set out as a dialogue between two men of learning, in which Spoudaeus (repraesenting the Scholer)

maketh doubtes, asketh Questions, obiecteth: yea, \& some tyme, digresseth not from the fonde imaginations of the grosse witted. Vn|to which, Philonicus (supplying th'office of à teacher) answereth to to all th'obiections, $\&$ giueth praeceptes. ${ }^{95}$

The full title of the work, The cosmographical glasse conteinyng the pleasant principles of cosmographie, geographie, hydrographie, or nauigation, continued the close relationship of those fields of geographical knowledge being practiced in Bristol by merchants decades before The Cosmographical Glasse was published. For Cuningham, the "glasse"—or mirror_of the world was reflected in the city below, and his cosmography is a working through of that link between city and cosmos, the city as a world. Following discussion of Ptolemy and the distinction between cosmography, geography and chorography, the "map" of Norwich is used by Cuningham to illustrate "chorography," noting "And finally for Chorographie, I haue placed

89 Lobel and Carus-Wilson, "Bristol" and Campbell, "Norwich." For free access to these two essays and their accompanying historical maps of Bristol and Norwich, see: http://www.historictownsatlas.org.uk/atlas/ volume-ii/atlas-historic-towns-volume-2.

90 William Hudson and John C. Tingey, eds., Records of the City of Norwich, Volume II (Norwich: Jarrold, 1910), 52.

91 Hudson and Tingey, Records of the City of Norwich, 52. Lilley, "Urban planning after the Black Death," 31.

92 H. Clifford Darby, The Draining of the Fens (Cambridge: Cambridge University Press, second edition, 1956). See Lawrence E. Harris, Vermuyden and the Fens. A Study of Sir Cornelius Vermuyden and the Great Level (London: Cleaver-Hume Press, 1953). Margaret Albright Knittl, "The design for the initial drainage of the Great Level of the Fens: an historical whodunit in three parts," Agricultural History Review 55(1) (2007): 23-50.

93 Raleigh A. Skelton and Paul D. A. Harvey, eds., Local Maps and Plans from Medieval England (Oxford: Clarendon, 1986), map at frontispiece.

94 William Cuningham, The Cosmographical Glasse, conteinyng the pleasant Principles of Cosmographie, Geographie, Hydrographie, or Nauigation (London: Iohannis Daij Typographi, 1559). Digital access to the ful volume is available free-to-view at: https://www.loc.gov/resource/rbctos.2017english41254 The map of Norwich appears between fol. 8 and fol. 9 and is also accessible free-to-view at: https://www.bl.uk/collectionitems/map-of-norwich. 


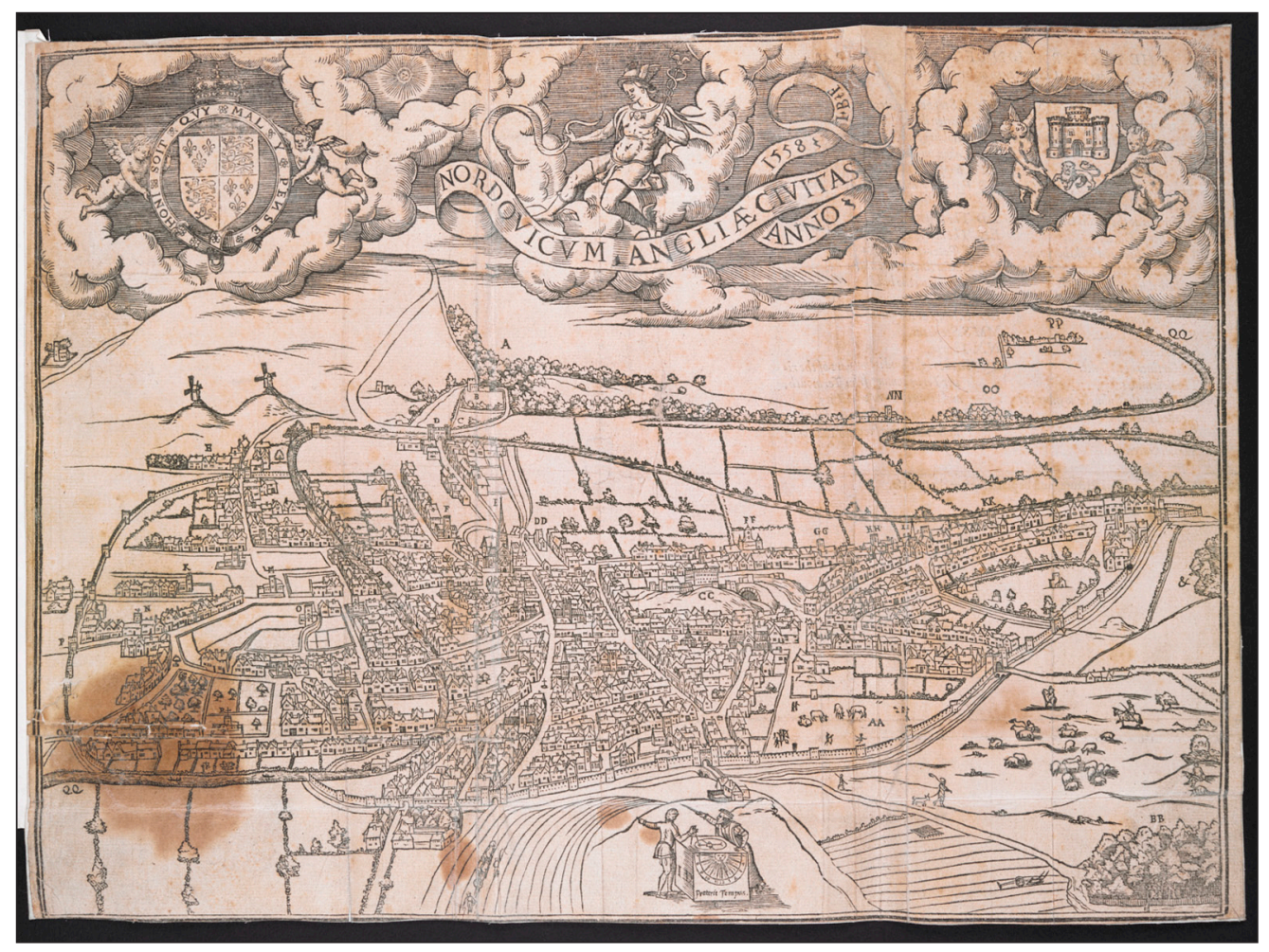

th'excellent Citie of Norwyche, as the forme of it is, at this present 1558." 96 Little else is said in the dialogue of the map, for which Cuningham actually uses the term "picture" to describe it, but at the base of the image, an oblique perspective rather than planimetric view of the city, two figures are observed, in a field overlooking the city to the south. ${ }^{97}$

Cuningham's map of Norwich is unlike that of Portsmouth of fifteen years earlier not just in terms of its use of perspective rather than planimetry, it differs too in having no constructional geometry visible on the image itself. Instead, what links the map of Norwich to Cuningham's exposition in The Cosmographical Glasse on map-making and field-survey is evident in the small vignette included on the map. ${ }^{98}$ Here, "the map" is visibly connected to "the field," literally, through the depiction of two surveyors. It would seem from their appearance, and stance, that the two figures represent the protagonists in the dialogue, Philonicus as the teacher, pointing to the city, and Spoudaeus as the pupil, with dividers in one hand, looking out and pointing with the other hand in the same direction towards the city as his instructor. Between them on a block or table is laid out a horizontal compass-rose, and on the side of this is a sundial, the two orientating between the heavens and the city, the vertical and the horizontal. Though the "picture" Cuningham includes is not a scaled plan of Norwich, it nevertheless captures the action and practice of map-making in the field, a mapping-site. Indeed, few contemporary English maps of towns and cities contain such self-references to the instruments and processes of their making, in- and of-the-field. Thus while William Smith's later map of Norwich, of 1588, seems to owe much to the image in The Cosmographical Glasse in terms of angle of view, orientation and composition, these two figures making their observations on the city, do not feature as if expunged from the map's making and so masking its origins and links to the city it represents. ${ }^{99}$

The Cosmographical Glasse while otherwise silent on the map of Norwich it contains, does offer a particularly important link between map and field. Indeed, the horizontal compass-rose depicted on the map begins to make sense in the dialogue between Philonicus and Spoudaeus that follows, as it is an instrument that Cuningham goes onto to describe in some detail in the
DOI: $10.16995 /$ lefou.96

Figure 4 View of Norwich, William Cuningham, The Cosmographical Glasse, conteinyng the pleasant Principles of Cosmographie, Geographie, Hydrographie, or Nauigation (London: Iohannis Daij Typographi, 1559), between fol. 8 and fol. 9, https://www.bl.uk/collectionitems/map-of-norwich.

96 Cuningham, Cosmographical Glasse, fol. 8. On the basis of that some of the buildings shown by Cuningham had disappeared from the townscape by $1558 / 59$, the suggestion has been made that his plan had been copied from an earlier but now lost view of Norwich: Barber, "Map making in England," 1655.

97 The term "picture" is used by Cuningham where he lists the features named on the map.

98 For the map see https://www.bl.uk/collection-items/map-of-norwich.

99 William Smith, "Particuler Description of England" (1588), British Library, Sloane MS 2596, fol. 61. See Harvey, Maps in Tudor England, 75. 
Third Book of the Cosmographical Glasse "in which is vttered the making and protracture, of the Face of th'Earth, both in Cartes Perticuler, and al|so vniuersall, with diuers necessarye thinges, incidente hereto." 100 Following an illustration of "An Instru|ment seruinge th'vse to des|cribe a countrey," Philonicus explains,

I will in fewe wordes make it to you euident. With youre Instrumente you shall ascende on some hie towre, Steaple, or Mountayne, so that you may on euery part se the townes, \& Uillagies, aboute you adiacent in your Horizont. Then placing your Instrument (which I name à Geographicall plaine Sphere) Flat, \& leuell, tourninge it from one parte vnto another, vntil the ne|dle fall on the Meridian Line, in thy Geographicall plaine Spheare, then it remaininge stedfaste: directe the ruler with hys two sightes vnto anye one place that you do see, \& marke diligently th' Angle of sight, (Gemma Frisius calleth it) Angulus positionis. ${ }^{101}$

The affinity with what the two figures overlooking Norwich are doing on the map in Book One is very close to the account of how to use the "Geographicall plaine Spheare" described by this passage. The planisphere, as it later becomes known, ${ }^{102}$ and its function as a cartographic and surveying instrument is clear, and so the map of Norwich (as a perspective) is really as much a device to show the field-operations using such an instrument, so suggestive to the reader that it was made by using such an even instrument even if it was not. Together the text and the image, relate the map to the field as a site of survey, a lieu de savoir, a place by which and through which geographical knowledge is made.

Cuningham's mention of Gemma Frisius is telling, for Cuningham had previously visited Heidelburg, "where he made many learned friends," for no doubt these acquaintances helped feed into Cuningham's knowledge and use of survey instruments as well as the practical mathematics of survey for map-making. ${ }^{103}$ His description of the planisphere is close to that of William Bourne, whose Treasure for Traueilers (London, 1578) also included a diagram for mapping from survey -based on angles between fixed points and using indirect measurement in the field-a diagram based on Frisius' Libellus de locorum describendorum ratione (Antwerp 1553). ${ }^{104}$ Bourne, like Cuningham, shared a friendship with John Dee, and in fact he dedicated the Cosmographical Glasse to Lord Robert Dudley, 1st Earl of Leicester, whose children Dee had had tutored. ${ }^{105}$ However, rather than including a version of Frisius' diagram on triangulation, as Bourne had done in Treasure for Traueilers - using his part of Kent around Gravesend to explain his survey method-Cuningham instead chose a much simpler illustration and exemplification of triangulation. ${ }^{106}$ Again a localised example is used. In explaining "you shall take your in|strument and Paper, trauelinge vnto some other town [...] \& so in like man|ner you shall do with other places, vntil you haue drawn the hole region you desire," Philonicus notes "how the worke is right easy," and to this end a diagrammatic map follows the description. ${ }^{107}$ Showing three places positioned in the shape of a triangle, one of these is Norwich. Once again, then, a local map is used to locate the Cosmographical Glasse, and thus a chorography of cosmography, the city as a world.

100 Cuningham, Cosmographical Glasse, fol. 111.

101 Cuningham, Cosmographical Glasse, fol. 137.

102 Eg. Aaron Rathborne, The Surveyor (London: William Stansby, 1616). Edmond R. Kiely, Surveying Instruments. Their History and Classroom Use (New York: Columbia University, 1947), 372.

103 Eva G. R. Taylor, Tudor Geography 1485-1583 (London: Methuen, 1930), 26.

104 William Bourne, Treasure for Traueilers (London: Thomas Woodcocke, 1578): 32v-29r [sic, i.e. 32v-33r]. Eva G. R. Taylor, ed., A Regiment for the Sea, and other Writings on Navigation, by William Bourne of Gravesend, a gunner, c. 1535-1582 (Hakluyt Society Second Series, No. CXXXI, 1963). Gemma Frisius, Libellus de locorum describendorum ratione (Antwerp, 1553). Alexander Pogo, "Gemma Frisius, his method of determining differences of longitude by transporting timepieces (1530), and his treatise on triangulation (1533)," Isis 22, no. 2 (1935): 469-506.

105 Cuningham, Cosmographical Glasse, "Praeface." On Dee, see Lesley Cormack, Charting an Empire: Geography at the English Universities 1580-1620 (Chicago, University of Chicago Press, 2003).

106 Cuningham, Cosmographical Glasse, fol. 140.

107 Cuningham, Cosmographical Glasse, fol. 139. This map is accessible online free-to-view at: https://www. loc.gov/resource/rbctos.2017english41254/?sp=160. 


\section{CONCLUSION-LIEUX DE SAVOIR IN THE PRACTICE OF URBAN CARTOGRAPHY}

As geographer Trevor Barnes observes, "Place is not mere background atmospherics but provides for the very possibility of intellectual innovation [...]." 108 Taking a traverse through three English provincial cities across three centuries reveals the enduring connections and continuities in the place of mapping in urban locales over time and space. Moreover, focusing on these "mappingsites" as lieux de savoir helps us to look beyond the map-image. This is important, as a fixation with the map-image over the years has emphasised cartographic difference, contributing to a history of mapping "revolution" marking "medieval" from the "modern." An "archaeology of cartography," placing maps and map-making within their locales of production, consumption and circulation, instead opens up a different view. The emphasis here is on "excavating" the practice of cartography and the spatial and temporal dynamic that emerges through mappingsites. This means thinking about the city as map-image and as map-place.

Comparing Chester, Bristol and Norwich and their urban mappings over three centuries, reveals a sustained and shared cartographic experience in cities otherwise differentiated geographically and temporally. These urban mappings transcend the historical divides often mobilised in histories of cartography that typically emphasise visual differences in map-images. For Higden, Ricart and for Cuningham, what unifies them as "cartographers" is not so much their representations of urban spaces, which clearly differ, but their practices. These practices in their particulars vary, of course, between the three men, but what they have in common with each other, what endures, is a concern for localising cartographic practise, connecting their cities and their maps. Looking behind the map, then, to mapping in and of the city, begins to break down what Del Casino and Hannah call the "binaries" so often separating cartographic practice and representation. ${ }^{109}$ They suggest, rather, "Thinking about map spaces in this way means neither the production nor the consumption of maps is separable from space in the most mundane of settings...," and "at the same time, spaces mediate people's experiences of maps."110 Here, the map can be seen as lieu de savoir, as a site of knowledge production and practice, a place embedded in and not separated from the map-image through those cartographic practices that made it. This is important more broadly, for as yet these lieux de savoir - while offering scope for exploring and understanding maps and map-makingremain overlooked in "critical cartography," at least in Anglophone histories of cartography which are rooted still very much in the ideas and work of J. Brian Harley, and his Foucauldian epistemology. ${ }^{111}$

Rather than simply placing maps in their institutional or patronage settings, with lieux de savoir in the practice of urban cartography the invitation is to look more closely at those sites of survey, locales of mapping, that shaped not only the history of cartography but those very places being mapped on the ground. Such a spatial dynamic is evident in Chester, Bristol and Norwich, where the map like the city is a reflection of those socio-spatial relations that created it. If the symbiosis of map and city is to be understood-and there is and clearly was a close and critical relationship between them-"It is thus critically important to attend to those venues that have generated knowledge-claims and then wielded them in different ways [...] At every scale, knowledge, space and power are tightly interwoven." ${ }^{112}$ Here, then, two central concepts in Foucault's thinking "on geography," power and knowledge and their spatial dynamic, yield to us a deeper and perhaps more critical rethinking of the "power of maps." Such power over territory, sovereignty and geography took place through the act of mapping, of not just representing places, landscapes and cities, but materially and viscerally rooting them in those places, in the field. To this end, taking an intersectional approach, "A whole history remains to be written of spaces." ${ }^{113}$ How the map sits within this wider landscape of powerrelations begins to be seen through their lieux de savoir.

108 Trevor Barnes, "Placing ideas: genius loci, heterotopia and geography's quantitative revolution," Progress in Human Geography 28(5) (2004): 565-95, at 568.

109 Vincent Del Casino and Stephen Hanna, "Beyond the 'binaries': a methodological intervention for interrogating maps as representational practices," ACME, an international e-journal for critical geographies 4, no. 1 (2006): 34-56.

110 Del Casino and Hanna, "Beyond the 'binaries, '" 44

111 Eg. see Dodge et al, eds., The Map Reader.

112 Livingstone, "Science, site and speech," 73.

113 Michel Foucault, "Questions on Geography," in Power Knowledge: Selected Interviews and Other Writings,

1972-1977, translated by Colin Gordon (New York: Pantheon Books, 1980), 149.
DOI: $10.16995 /$ lefou.96 
AUTHOR AFFILIATION

Keith D. Lilley (D) orcid.org/0000-0002-9513-6423

Queen's University Belfast, GB

\section{BIBLIOGRAPHY}

Albright Knittl, Margaret. "The design for the initial drainage of the Great Level of the Fens: an historical whodunit in three parts." Agricultural History Review 55, no. 1 (2007): 23-50.

Andrews, John. "Meaning, knowledge and power in the map philosophy of J.B. Harley." In The New Nature of Maps: Essays in the History of Cartography, edited by Paul Laxton, 1-32. Baltimore/London: Johns Hopkins University Press, 2001.

Andrews, John, and Sarah Bendall, "Draft maps of Galway and Coventry for John Speed's Theatre of the Empire of Great Britaine." Imago Mundi 58, no. 1 (2006): 77-9. DOI: https://doi. org/10.1080/03085690500362371

Babington, Charles and Joseph R. Lumby, eds. Polychronicon Ranulphi Higden Monachi Cestrensis; together with the English Translation of John Trevisa and of an Unknown Writer of the fifteenth century. London: Rolls Series, 1865-86.

Baker, Nigel, and Richard Holt. Urban Growth and the Medieval Church. Gloucester and Worcester. London: Routledge, 2004.

Barber, Peter. "Mapmaking in England, ca.1470-1650." In The History of Cartography, Vol. 3. Cartography in the European Renaissance (part 2), edited by David Woodward, 1589-669. Chicago: Chicago University Press, 2007.

Barnes, Trevor. "Placing ideas: genius loci, heterotopia and geography's quantitative revolution." Progress in Human Geography 28, no. 5 (2004): 565-95. DOI: https://doi.org/10.1191/0309132504ph506oa

Bendall, Sarah. "Plane table." In The History of Cartography, Volume 4. Cartography in the European Enlightenment (part 1), edited by Matthew Edney and Mary Sponberg Pedley, 675-77. Chicago: Chicago University Press, 2020.

Boonstra, Pieter. "In Ecclesia Nostra: The Collatiehuis in Gouda and its Lieux de Savoir." Le foucaldien 7, no. 1 (2021). DOI: https://doi.org/10.16995/lefou.93

Bourne, William. Treasure for Traueilers. London: Thomas Woodcocke, 1578.

Buisseret, David, ed. Monarchs, Ministers and Maps. The Emergence of Cartography as a Tool of Government in Early Modern Europe. Chicago: Chicago University Press, 1992.

Calbérac, Yann, "Close Reading Michel Foucault's and Yves Lacoste's Concepts of Space Through Spatial Metaphors," Le foucaldien 7, no. 1 (2021). DOI: https://doi.org/10.16995/lefou.90

Campbell, James. "Norwich." In The Atlas of Historic Towns, Volume 2. Ed. Mary D. Lobel. Oxford: The Scolar Press/Historic Towns Trust, 1975.

Clarke, Catherine, ed. Mapping the Medieval City: Space, Place and Identity in Chester c. 1200-1600. Cardiff: University of Wales Press, 2011.

Colvin, Howard M., ed. The History of the King's Works, volume 4: 1485-1660 (Part 2). London: Her Majesty's Stationery Office, 1982.

Cormack, Lesley. Charting an Empire: Geography at the English Universities 1580-1620. Chicago: University of Chicago Press, 2003.

Cosgrove, Denis, ed. Mappings. London: Reaktion, 1999.

Crampton, Jeremy. "Maps as social constructions: power, communication and visualization." Progress in Human Geography 25 (2001): 235-252. DOI: https://doi.org/10.1191/030913201678580494

Crampton, Jeremy, and John Krygier. "An introduction to critical cartography." ACME, an international e-journal for critical geographies 4, no. 1 (2006): 11-33.

Crick, Julia C., ed. The Historia regum Britanniae of Geoffrey of Monmouth. Boydell \& Brewer, Woodbridge: 1991.

Cuningham, William, The Cosmographical Glasse, conteinyng the pleasant Principles of Cosmographie, Geographie, Hydrographie, or Nauigation. London: Iohannis Daij Typographi, 1559.

Darby, H. Clifford. The Draining of the Fens. Cambridge: Cambridge University Press, second edition, 1956.

Del Casina, Vincent, and Stephen Hanna. "Beyond the 'binaries': a methodological intervention for interrogating maps as representational practices." ACME, an international e-journal for critical geographies 4, no. 1 (2006): 34-56.

Dodge, Martin, Rob Kitchin, and Chris Perkins, eds. The Map Reader: Theories of Mapping Practice and Cartographic Representation. Chichester: Wiley-Blackwell, 2011. DOI: https://doi. org/10.1002/9780470979587

Dreer, Cornelia, and Keith D. Lilley. "Universal histories and their geographies: navigating the maps and texts of Higden's Polychronicon." In Finding your Place in History and Politics: the life of universal chronicles in the high Middle Ages, edited by Michele Campopiano and Henry Bainton, 275-301. Woodbridge: Boydell and Brewer/York Medieval Press. DOI: https://doi. org/10.1017/9781787440333.012 
Edney, Matthew. "Field/Map: An historiographic review and reconsideration." In Scientists and Scholars in the Field: Studies in the History of Fieldwork and Expeditions, edited by Kristian H. Nielsen, Michael Harbsmeier and Christopher J. Ries, 431-56. Aarhus: Aarhus University Press, 2012.

Edson, Evelyn. Mapping Time and Space. How Medieval Map Makers Viewed their World. London: British Library: 1997.

Edson, Evelyn. The World Map, 1300-1492: The Persistence of Tradition and Transformation. Baltimore/ London: Johns Hopkins University Press, 2007.

Faulkner, Mark. "The spatial hermeneutics of Lucian's De Laude Cestrie." In Mapping the medieval City: space, place and identity in Chester c. 1200-1600, edited by Catherine Clarke, 78-98. Cardiff: University of Wales Press, 2011.

Feintuck, Anna. "Constructing cartographic authority: The conceptualization and mapping of urban spaces in Edinburgh, c.1880-c.1920." Urban History 46, no. 3 (2019): 464-92. DOI: https://doi.org/10.1017/ S0963926818000585

Fermon, Paul. Le Peintre et la carte. Origines et essor de la vue figurée entre Rhône et Alpes (XIVe-XVe siècle). Turnhout: Brepols, 2018.

Fleming, Peter. "Making history: culture, politics and The Maire of Bristowe Is Kalendar." In Reputation and Representation in Fifteenth-Century Europe, edited by Douglas L. Biggs, Sharon D. Michalove and A. Compton Reeves, 289-316. Leiden/Boston: Brill, 2004.

Fleming, Peter, ed. The Maire of Bristowe is Kalendar. Bristol Record Society, Vol. 67, 2015.

Fontana, Dominic. "Charting the development of Portsmouth harbour, dockyard and town in the Tudor Period." Journal of Maritime Archaeology 8 (2013): 263-282. DOI: https://doi.org/10.1007/s11457013-9114-4

Foucault, Michel. "Questions à Michel Foucault sur la géographie." Hérodote: revue de géographie et de géopolitique 1 (1976): 71-85.

Foucault, Michel. "Questions on Geography." In Power Knowledge: Selected Interviews and Other Writings, 1972-1977, translated by Colin Gordon. New York: Pantheon Books, 1980.

Frisius, Gemma. Libellus de locorum describendorum ratione. Antwerp, 1553.

Galbraith, Vivian H. "An Autograph MS of Ranulph Higden's Polychronicon." The Huntington Library Quarterly 23 (1959): 1-18. DOI: https://doi.org/10.2307/3816473

Gerbino, Anthony. "Mastering the landscape: geometric survey in sixteenth-century France." The Art Bulletin 100, no. 4 (2018): 7-33. DOI: https://doi.org/10.1080/00043079.2018.1464357

Giard, Luce, Christian Jacob, Marc-Olivier Padis, and Diane Sempere. "Les lieux de savoir: Pour une nouvelle cartographie des savoirs." Esprit 348, no. 10 (2008): 42-59. DOI: https://doi.org/10.3917/ espri.0810.0042

Hale, John R. "The Defence of the Realm, 1485-1558." In The History of the King's Works, volume 4: 14851660 (Part 2), edited by Howard M. Colvin, 367-401. London: Her Majesty's Stationery Office, 1982.

Harley, J. Brian. "Deconstructing the map." Cartographica 26, no. 2 (1989): 1-20. DOI: https://doi. org/10.3138/E635-7827-1757-9T53

Harley, J. Brian, "Maps, knowledge and power." In The Iconography of Landscape. Essays on the Symbolic Representation, Design and Use of Past Environments, edited by Denis Cosgrove and Stephen Daniels, 277-312. Cambridge: Cambridge University Press, 1988.

Harley, J. Brian. "Meaning and ambiguity in Tudor cartography." in English Map-Making 1500-1650, edited by Sarah Tyacke, 22-45. London: The British Library, 1983.

Harley, J. Brian. The New Nature of Maps: essays in the history of cartography, edited by Paul Laxton. Baltimore/London: Johns Hopkins University Press, 2001.

Harris, Lawrence E. Vermuyden and the Fens. A Study of Sir Cornelius Vermuyden and the Great Level. London: Cleaver-Hume Press, 1953. DOI: https://doi.org/10.1097/00010694-195401000-00029

Harvey, John, ed. William Worcestre, Itineraries. Oxford: Clarendon Press, 1969.

Harvey, Paul D.A. Maps in Tudor England. Chicago: Chicago University Press, 1993.

Harvey, Paul D.A., ed. The Hereford World Map: Medieval World Maps and their Context. London: The British Library, 2006.

Harvey, Paul D.A. "The Portsmouth Map of 1545 and the introduction of scale maps into England." In Hampshire Studies, edited by John Webb, Nigel Yates and Sarah E. Peacock, 33-49. Portsmouth: Portsmouth City Records Office, 1981.

Hoogvliet, Margriet. "The medieval texts of the 1486 Ptolemy Edition by Johann Reger of Ulm." Imago Mundi 54 (2002): 7-18. DOI: https://doi.org/10.1080/03085690208592955

Hoogvliet, Margriet, and Sabrina Corbellini. "Writing as a religious Lieu de Savoir." Le foucaldien 7, no. 1 (2021). DOI: https://doi.org/10.16995/lefou.92

Hudson, William, and John C. Tingey, eds. Records of the City of Norwich, Volume II. Norwich: Jarrold, 1910.

Ingeldew, Francis. "The Book of Troy and the genealogical construction of history: the case of Geoffrey of Monmouth's Historia regum Britanniae." Speculum 69 (1994): 665-704. DOI: https://doi. org/10.2307/3040847 
Jacob, Christian. Des Mondes Lettrés aux Lieux de Savoir. Paris: Les Belles Lettres, 2018.

Jacob, Christian, ed. Lieux de Savoir: Espaces et Communautés. Paris: Albin Michel, 2007.

Jacob, Christian. "Lieux de savoir: Places and Spaces in the History of Knowledge." KNOW: A Journal on the

Formation of Knowledge 1, no. 1 (2017): 85-102. DOI: https://doi.org/10.1086/692293

Jacob, Christian, ed. Lieux de savoir. Vol 2, Les mains de l'intellect. Paris: Albin Michel, 2011.

Jacob, Christian. Qu'est-ce qu'un lieu de savoir? Marseille: OpenEdition Press, 2014. DOI: https://doi. org/10.4000/books.oep.423

Jacob, Christian. The Sovereign Map. Theoretical Approaches in Cartography throughout History. Chicago: University of Chicago Press, 2006.

Kiely, Edmond R. Surveying Instruments. Their History and Classroom Use. New York: Columbia University, 1947.

Klein, Bernhard. Maps and the Writing of Space in Early Modern England and Ireland. New York: Palgrave, 2001. DOI: https://doi.org/10.1057/9780230598119

Kogman-Appel, Katrin. Catalan Maps and Jewish Books. The Intellectual Profile of Elisha ben Abraham Cresques (1325-1387). Turnhout: Brepols, 2020.

Laughton, Jane. Life in a Late Medieval City: Chester, 1275-1520. Oxford: Oxbow Books, 2008.

Lavezzo, Kathy. Angels on the Edge of the World: Geography, Literature, and English Community, 10001534. Ithaca/London: Cornell University Press, 2006.

Lilley, Keith D. City and Cosmos. The Medieval World in Urban Form. London: Reaktion, 2009.

Lilley, Keith D., ed. Mapping Medieval Geographies. Geographical encounters in the Latin West and beyond, 300-1600. Cambridge: Cambridge University Press, 2014. DOI: https://doi.org/10.1017/ CB09781139568388

Lilley, Keith D. "Mapping the nation: Landscapes of survey and the material cultures of the early Ordnance Survey in Britain and Ireland." Landscapes 18, no. 2 (2018): 178-99. DOI: https://doi.org/10.1080/146 62035.2018.1429717

Lilley, Keith D. "Materialising the city: mapping in the imaging and imagining of medieval urban spaces." In Kommunale Selbstinszenierung. Städtische Konstellationen zwischen Mittelalter und Neuzeit, edited by Martina Stercken and Christian Hesse, 241-53. Zürich: Chronos Verlag, 2018.

Lilley, Keith D. "Surveying empires: Archaeologies of colonial cartography and the Great Trigonometrical Survey of India." In Mapping Empires: Colonial Cartographies of Land and Sea, edited by Alexander Kent, Soetkin Vervust, Imre Demhardt and Nick Millea, 101-20. Berlin/Heidelburg: Springer International Publishing, 2019. DOI: https://doi.org/10.1007/978-3-030-23447-8_6

Lilley, Keith D. "Urban planning and the design of towns in the Middle Ages: The Earls of Devon and their 'new towns.'" Planning Perspectives 16 (2001): 1-24. DOI: https://doi. org/10.1080/02665430010000751

Lilley, Keith D. "Urban planning after the Black Death: Townscape transformations in later-medieval England (1350-1530)." Urban History 42, no. 1 (2015): 22-42. DOI: https://doi.org/10.1017/ S0963926814000492

Lilley, Keith D., and Christopher D. Lloyd. "Mapping the realm: a new look at the Gough Map of Britain (c.1360)." Imago Mundi 61, no. 1 (2009): 1-28. DOI: https://doi.org/10.1080/03085690802456228

Livingstone, David N. Putting Science in its Place. Chicago/London: Chicago University Press, 2003. DOI: https://doi.org/10.7208/chicago/9780226487243.001.0001

Livingstone, David N. "Science, site and speech: scientific knowledge and the spaces of rhetoric." History of the Human Sciences 20 (2007): 71-98. DOI: https://doi.org/10.1177/0952695107076516

Livingstone, David N., and Charles W. J. Withers, eds. Geographies of Nineteenth-Century Science. Chicago: University of Chicago Press, 2011. DOI: https://doi.org/10.7208/chicago/9780226487298.001.0001

Lobel, Mary D., and Eleanor M. Carus-Wilson. "Bristol." In The Atlas of Historic Towns, Volume 2, edited by Mary D. Lobel. Oxford: The Scolar Press/Historic Towns Trust, 1975.

Mayhew, Robert, and Charles W J Withers. eds. Geographies of Knowledge. Science, scale, and spatiality in the nineteenth century. Baltimore/London: Johns Hopkins University Press, 2020.

Merriman, Marcus. "Italian military engineers in Britain in the 1540s." In English Map-Making 1500-1650, edited by Sarah Tyacke, 57-67. London: British Library, 1983.

Millea, Nick. The Gough Map: The Earliest Road Map of Great Britain? Oxford: Bodleian Library, 2007.

Miller, Naomi. Mapping the City. The Language and Culture of Cartography in the Renaissance. New York: Continuum, 2003.

Perkins, Chris. "Cartography: cultures of mapping, power in practice." Progress in Human Geography 28 (2004): 381-339. DOI: https://doi.org/10.1191/0309132504ph504pr

Pickles, John. A History of Spaces: Cartographic Reason, Mapping and the Geo-coded World. London: Routledge, 2004.

Pinto, John A. "Origins and development of the ichnographic city plan." Journal of the Society of Architectural Historians 35 (1976): 35-50. DOI: https://doi.org/10.2307/988969

Pogo, Alexander. "Gemma Frisius, his method of determining differences of longitude by transporting timepieces (1530), and his treatise on triangulation (1533)." Isis 22(2) (1935): 469-506. DOI: https:// doi.org/10.1086/346920 
Porter, Cat, Keith D. Lilley, Christopher D. Lloyd, Siobhán McDermott, and Rebecca Milligan. "Cartographic connections - the digital analysis and curation of sixteenth-century maps of Great Britain and Ireland." e-Perimetron 14, vol. 2 (2019): 97-109.

Quinn, David B. England and the discovery of America, 1481-1620: from the Bristol voyages of the fifteenth century to the Pilgrim settlement at Plymouth: the exploration, exploitation, and trial-and-error colonization of North America by the English. New York: Alfred A. Knopf, 1974.

Rathborne, Aaron, The Surveyor. London: William Stansby, 1616.

Relph, Elizabeth. "Bristol, circa 1480." In Local Maps and Plans from Medieval England, edited by Raleigh A. Skelton and Paul D. A. Harvey, 309-16. Oxford: Clarendon Press, 1986.

Riley, Henry T. ed. Memorials of London and London Life: In the 13th, 14th and 15th Centuries. London: Longmans, Green \& Co., 1868.

Skelton, Raleigh A. "Ranulf Higden." In Mappemondes A.D. 1200-1500, Monumenta cartographica vetustioris aevi 1, edited by Marcel Destombes, 149-60. Amsterdam: N. Israel, 1964.

Skelton, Raleigh A., and Paul D.A. Harvey, eds. Local Maps and Plans from Medieval England. Oxford: Clarendon, 1986.

Smith, William. "Particuler Description of England" (1588). British Library, Sloane MS 2596.

Taylor, Eva G.R., ed. A Regiment for the Sea, and other Writings on Navigation, by William Bourne of Gravesend, a gunner, c. 1535-1582. Hakluyt Society Second Series, No. CXXXI, 1963.

Taylor, Eva G.R. Tudor Geography 1485-1583. London: Methuen, 1930.

Taylor, John. The Universal Chronicle of Ranulf Higden. Oxford: Clarendon Press, 1966.

Thomas, A.H., and Isobel D. Thornley, eds. The Great Chronicle of London. London: Corporation of the City of London, 1939.

Thrower, Norman, ed. The Compleat Plattmaker. Essays on Chart, Map and Globe-making in England in the Seventeenth and Eighteenth Centuries. Los Angeles: UCLA Press, 1978.

Toulmin Smith, Lucy, ed. The Maire of Bristowe is Kalendar, c. 1480. Camden Society, New Series 5, 1872.

Van Damme, Stéphane. "When practices, places and materiality matter: a French trajectory in the history of knowledge." Journal for the History of Knowledge 1, no. 1 (2020): 4. DOI: https://doi.org/10.5334/ jhk.26

Van Putten, Jasper. Networked Nation. Mapping German Cities in Sebastian Münster's 'Cosmographia.' Leiden/Boston: Brill, 2018. DOI: https://doi.org/10.1163/9789004353961

Westropp, Thomas J. "Brasil and the legendary islands of the North Atlantic: their history and fable. A contribution to the 'Atlantis' problem." Proceedings of the Royal Irish Academy 30 (1912-13): 223-60.

Williamson, James A., ed. The Cabot Voyages and Bristol Discovery under Henry VII Hakluyt Society, 2nd series 120 (1962).

Wilson, Eleanor M. Carus. The Overseas Trade of Bristol in the later Middle Ages. Bristol Record Society, Vol. 7 (1937).

Wood, Denis. The Power of Maps. London: Routledge, 1993. DOI: https://doi.org/10.1038/ scientificamerican0593-88

Woodward, David, ed. The History of Cartography, Vol. 3. Cartography in the European Renaissance (part 2). Chicago: Chicago University Press, 2007.

\author{
TO CITE THIS ARTICLE: \\ Keith D. Lilley. "Mapping \\ Sites: Lieux de Savoir in the \\ Practice of Urban Cartography, \\ 1340-1560." Le foucaldien \\ 7, no. 1 (2021): 7, pp. 1-22. \\ DOI: https://doi.org/10.16995/ \\ lefou.96
}

Submitted: 21 October 2020 Accepted: 02 June 2021 Published: 05 July 2021

COPYRIGHT:

(C) 2021 The Author(s). This is an open-access article distributed under the terms of the Creative Commons Attribution 4.0 International License (CC BY 4.0), which permits unrestricted use, distribution, and reproduction in any medium, provided the original author and source are credited. See http://creativecommons.org/ licenses/by/4.0/.

Le foucaldien is a peerreviewed open access journal published by Open Library of Humanities. 